\title{
Production of Ultra-High-Performance Concrete with Low Energy Consumption and Carbon Footprint Using Supplementary Cementitious Materials Instead of Silica Fume: A Review
}

\author{
Mays A. Hamad ${ }^{1}$, Mohammed Nasr ${ }^{2}{ }^{(}$, Ali Shubbar ${ }^{3}{ }^{\circ}$, Zainab Al-Khafaji ${ }^{4}$, Zainab Al Masoodi ${ }^{5}$,

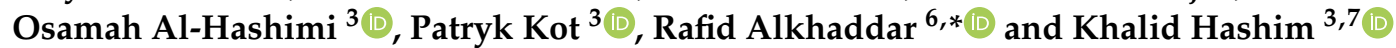

check for updates

Citation: Hamad, M.A.; Nasr, M.; Shubbar, A.; Al-Khafaji, Z.; Al Masoodi, Z.; Al-Hashimi, O.; Kot, P.; Alkhaddar, R.; Hashim, K. Production of Ultra-High-Performance Concrete with Low Energy Consumption and Carbon Footprint Using Supplementary Cementitious Materials Instead of Silica Fume: A Review. Energies 2021, 14, 8291. https://doi.org/10.3390/en14248291

Academic Editors: F. Pacheco Torgal and Paulo Santos

Received: 7 November 2021

Accepted: 6 December 2021

Published: 9 December 2021

Publisher's Note: MDPI stays neutral with regard to jurisdictional claims in published maps and institutional affiliations.

Copyright: (c) 2021 by the authors. Licensee MDPI, Basel, Switzerland. This article is an open access article distributed under the terms and conditions of the Creative Commons Attribution (CC BY) license (https:// creativecommons.org/licenses/by/ $4.0 /)$.
1 Building and Construction Engineering Technology Department, Al-Mustaqbal University College, Hillah 51001, Iraq; mays.abdal_redha@mustaqbal-college.edu.iq

2 Technical Institute of Babylon, Al-Furat Al-Awsat Technical University (ATU), Babylon 51015, Iraq; mohammed.nasr@atu.edu.iq

3 School of Civil Engineering and Built Environment, Liverpool John Moores University, Liverpool L3 3AF, UK; A.A.Shubbar@ljmu.ac.uk (A.S.); O.A.AlHashimi@2020.ljmu.ac.uk (O.A.-H.); P.Kot@ljmu.ac.uk (P.K.); K.S.Hashim@ljmu.ac.uk (K.H.)

4 Al-Furrat Al-Awsat Distribution Foundation, Ministry of Oil, Babylon 51001, Iraq; zainabcivil90@gmail.com

5 National Center for Construction Laboratories (NCCL), Ministry of Construction and Housing, Babylon 51001, Iraq; Zainab.ob93@gmail.com

6 Dean of Academic Affairs, Oryx Universal College in Partnership with LJMU, Doha P.O. Box 12253, Qatar

7 Department of Civil Engineering, College of Engineering, University of Babylon, Babylon 51001, Iraq

* Correspondence: r.m.alkhaddar@ljmu.ac.uk

\begin{abstract}
The increase in cement production as a result of growing demand in the construction sector means an increase in energy consumption and $\mathrm{CO}_{2}$ emissions. These emissions are estimated at $7 \%$ of the global production of $\mathrm{CO}_{2}$. Ultra-high-performance concrete (UHPC) has excellent mechanical and durability characteristics. Nevertheless, it is costly and affects the environment due to its high amount of cement, which may reach $800-1000 \mathrm{~kg} / \mathrm{m}^{3}$. In order to reduce the cement content, silica fume (SF) was utilized as a partial alternative to cement in the production of UHPC. Nevertheless, SF is very expensive. Therefore, the researchers investigated the use of supplementary cementitious materials cheaper than SF. Very limited review investigates addressed the impact of such materials on different properties of UHPC in comparison to that of SF. Thus, this study aims to summarize the effectiveness of using some common supplementary cementitious materials, including fly ashes (FA), ground granulated blast furnace slag (GGBS), metakaolin (MK) and rice husk ashes (RHA) in the manufacturing of UHPC, and comparing the performance of each material with that of SF. The comparison among these substances was also discussed. It has been found that RHA is considered a successful alternative to SF to produce UHPC with similar or even higher properties than SF. Moreover, FA, GGBS and MK can be utilized in combination with SF (as a partial substitute of SF) as a result of having less pozzolanic activity than SF.
\end{abstract}

Keywords: ground granulated blast furnace slag; metakaolin; rice husk ashes; silica fume; ultra-highperformance concrete

\section{Introduction}

The increase in $\mathrm{CO}_{2}$ emissions is a concern of scientists at the present time, due to its negative impact on the environment and global warming. One of the main industries contributing to the increase in these emissions is cement production. Ultra-high performance concrete (UHPC) or identified as reactive powder concrete (RPC) point to a new category of materials based on cement that exhibited exceptional mechanical and durability characteristics [1-5]. The compressive strength of 200-800 MPa was obtained for 
UHPC worldwide [6-11]. UHPC is designed with a very low water/binder proportion $(<0.2)$ and an appointed amount of reinforcing fibers, depending on the fundamentals of tightening packing between particles of each ingredient $[12,13]$. The typical mixture of UHPC comprises cement, supplementary cementitious materials (SCMs, including fly ashes, metakaolin, silica fume, etc.), sand (fine sand), glass or quartz powder, high-range water-reducing admixture (HRWR), low water content and steel fibers [14-17]. Coarse aggregate is eliminated in most UHPC mixtures [14,18-20] to increase the homogeneity, overcome the weakness at the interfacial transition area between the coarse aggregate and paste matrix, as well as remove the stress concentration at the contact points between the coarse aggregate particles [21-23].

Different curing systems were applied for UHPC such as water (standard), steam and autoclave (accelerated) curing, which achieved various compressive strengths [9,24-26]. By applying the autoclave, an increase in compressive strength by $20-30 \%$ is recorded, and thus it is thought to be the best type of curing for UHPC [24,27]. Nevertheless, using such accelerated curing may restrict the field production of UHPC and increase its cost [28-30].

Recently, the use of UHPC in various applications has increased to include bridges, building components, off-shore structures, architectural features, utility towers to oil and gas industry applications, repair and rehabilitation, overlay materials, hydraulic structures and windmill towers [31,32]. Nevertheless, the major challenge that still limits the wide application of UHPC is the high cost of its production [33-36].

The cement content in UHPC may reach up to $800-1000 \mathrm{~kg} / \mathrm{m}^{3}$, which indicates high hydration heat, shrinkage problems and a high cost of production [37]. Additionally, a high amount of carbon dioxide is emitted into the atmosphere [38]. The carbon dioxide produced in the cement industry is estimated at 7\% of global production annually [39-43]. Silica fume (SF) is usually utilized to partially replace the cement (and thus reduce the cement content) to enhance the cement matrix characteristics in UHPC [44]. The typical content of SF in UHPC is approximately $25 \%$ (by binder materials weight) $[45,46]$. SF, which was initially considered industrial waste, has become one of the best industrial byproducts for the production of cement and concrete materials, and its required quantities are constantly increasing [1,47]. Nevertheless, SF is very expensive [48]. Hence, there is an urgent requirement to search for possible lower-cost alternative materials in UHPC preparation [1]. It seems that substituting cement with mineral additives and reducing SF amount represents a possible solution to these issues [49-54]. Some common SCMs utilized in UHPC as alternatives to SF were fly ash (FA), ground granulated blast-furnace slag (GGBS), metakaolin (MK) and rice husk ash (RHA) [55-59].

Much research regarding the raw materials and mix design $[3,60]$, as well as the microstructure and properties [22,61-64] of UHPC, have been performed in the past years. The most recent reviews discussed the performance evaluation [65] and the UHPC behavior under high temperatures [66]. Limited investigates summarized the performance of SCMs (other than SF) as alternatives to SF in UHPC and their impact on its different properties in comparison to SF. Most of the previous reviews discussed the general characteristics obtained when using SCMs in UHPC, and did not clearly address the comparison among the performance of these materials and to that of SF. SF is an expensive material, which in turn affects the total cost of UHPC. Thus, it is worthwhile to study the feasibility of the other SCMs that are cheaper than SF to be used as successful alternatives in terms of the different properties of the resulting UHPC. Thus, this paper discussed the use of four commonly utilized materials (FA, MK, GGBS and RHA) in the manufacturing of UHPC as a partial or full replacement of SF. The overall comparison among these materials' performance was also addressed.

\section{Critical Evaluation of State-of-Art}

In this study, the production of UHPC using SCMs other than silica fume is divided into four groups: utilization of FA in the production of UHPC; utilization of GGBS in the 
production of UHPC; utilization of MK in the preparing of UHPC; and utilization of RHA in the production of UHPC. The environmental impact of these SCMs were also included.

\subsection{Utilization of FA in the Production of UHPC}

FA is a waste substance that is generated in the power generation industry from coal combustion processes. Unlike lime and cement, fly ash has no cementitious characteristics that enable it to harden by its own properties [67]. FA is a fine powder substance, and its particles are circular in form and almost glassy in nature, formed in a hollow or solid-state for the rest. Nevertheless, the incomplete incineration materials in the FA also had an angular form. Based on the form of fired coal and the combustion rate, the chemical structure of fly ashes varies. As well as other forms of fly ashes that could exist from other sectors rather than the power generation sector, there are two major groups of fly ashes: class F and class C. Silica and calcium amounts in the chemical formulations, along with iron percentage, is the prevailing factor between classes $\mathrm{F}$ and $\mathrm{C}$. Class F fly ashes is correlated with a lower calcium amount than Class C, as FA Class F does not yet have a cementitious reactivity, but its amount of pozzolanic materials is adequately high to enhance the pozzolanic reaction, leading to an increase in the production of cementitious products, due to an increase in compressive strength [68]. Fly ashes' performance has been confirmed to be mainly based on particle size, $\mathrm{CaO}$ and iron amount and ignition losses [69]. The following investigations utilized different types of FA in the production of UHPC.

Yazici et al. [50] investigated the impact of partial substitution of the SF and cement by FA and/or GGBFS on the performance of RPC. Results indicated that the compressive strength of concrete containing mineral additives was $281 \mathrm{MPa}$. When the external pressure was applied in the setting and hardening phase, this value increased to $324 \mathrm{MPa}$. Moreover, their test outcomes specified that the utilizing of FA alone in RPC is potential without an essential mechanical behavior loss with increasing the FA content. They also found that the performance of RPC enhanced for mixtures incorporated GGBFS in combination with FA.

Yaz1c1 et al. [70] investigated the mechanical properties of RPC made with either class-C FA or a combination of class-C FA and GGBFS under standard, steam and autoclave curing systems. The FA was utilized in the percentages of $10 \%, 20 \%$ and $30 \%$ (by weight of cement), while GGBS was utilized in the percentages of $10 \%$ (by weight of cement). SF was utilized in all mixtures (in proportions of about 15\% to $26 \%$ ) together with FA and/or GGBS. Results indicated that though RPC incorporated less content of cement and SF and a high volume of FA and/or GGBS comparison with the reference RPC, the compressive strength exceeded $200 \mathrm{MPa}$ under standard curing. Moreover, SF can be reduced as a result of using FA and/or GGBFS as a fine silica source. Furthermore, a dense microstructure was revealed by Scanning Electron Microscopy (SEM). The use of steam and autoclave curing increased the 28-days compressive strength to 234 and $250 \mathrm{MPa}$ respectively. On the other hand, accelerated curing reduced the flexural strength and toughness compared to standard curing.

Yiğiter et al. [10] investigated producing low cement RPC by incorporating high volume class-C FA $(20 \%, 40 \%$ and $60 \%)$ as a replacement material for cement. The control mixture (free of FA) and FA-based RPC mixtures contained 30\% SF (by weight of cement). Different curing systems were considered (autoclave, steam and standard curing). The fracture energy, the strengths of compressive, flexural and splitting tensile were examined. Results indicated that the compressive strength of $200 \mathrm{MPa}$ was obtained using highvolume FA. A value of $400 \mathrm{MPa}$ was achieved for compressive strength for the reference mixture after pressure application throughout the setting and hardening stage, and then autoclaving. The corresponding compressive strength value of $60 \%$ FA was $338 \mathrm{MPa}$. Moreover, the flexural strength and splitting tensile strength of FA-based RPC were comparable to that of the control mix.

Ahmad et al. [44] developed UHPC which included partial replacing of silica fume and sand by industrial waste and natural materials (locally available in Saudi Arabia). 
SF (40 percent, 60 percent and 80 percent) was partly substituted by fly ashes (FA). In order to eventually choose certain mixtures that met the UHPC min flow and strength requirements, the flow and 28-day compressive strength for every UHPC mixture were specified. The finding of the test indicated that the usage of FA in UHPC output is feasible with sufficient flow and strength. The compressive strength values were 150, 158 and $143 \mathrm{MPa}$ for replacement levels of $40 \%, 60 \%$ and $80 \%$ respectively. Therefore, the optimum replacing ratio of SF by FA was $60 \%$.

Ferdosian et al. [71] conducted an experimental study to replace the two main constituents of UHPC, cement and silica fume (to reduce the high cost and environmental impacts of UHPC) by fly ashes. The flowability and compressive strength at 28 days were investigated. The impact of FA particle size on these characteristics was investigated. FA was utilized in proportions of $10 \%$ to $35 \%$ with and without $5 \%$ SF and $2.5 \%$ MK. Results indicated that the particle size of FA had an important role in the pozzolanic activity of FA, where using ultra-fine FA $(4.48 \mu \mathrm{m})$ in a replacement level of $20 \%$ could enhance the fluidity and compressive strength (153 MPa at 28 days) of UHPC under standard curing. Furthermore, it was found that adding at least $5 \%$ of SF is a prerequisite for increasing the strength of UHPC paste.

Zhang et al. [72] conducted an experimental study to forecast the UHPC compressive strength-incorporated SCMs. The microstructure and mechanical characteristics of UHPC incorporating class-C FA and SF were examined. SF replaced the cement by 5\%, 10\%, $15 \%$ and $20 \%$, while FA replaced the cement by 30\%. The results were compared with the reference mixture, which was made with 5\% SF (without FA). Results showed that the UHPC made with $30 \%$ FA and 20\% SF gave comparable mechanical characteristics as those of reference specimens. Additionally, the highest compressive strength was achieved for UHPC made with 30\% FA and 20\% SF. The pore volume and microstructure had a strong correlation with the mechanical properties. Moreover, it was found that the developed ANN (Artificial Neural Network) model is highly accurate, and can be utilized to forecast the UHPC compressive strength with SCMs.

Bahedh and Jaafar [73] utilized Class-F fly ashes in proportions of $0 \%$ (the control mix) to $40 \%$ in step of $10 \%$ as cement replacement in UHPC. The mechanical and permeability characteristics of UHPC were investigated under water and autoclaving curing situations. The impact of the autoclave duration was also observed. Results indicated that the higher the FA dosage, the higher the workability of concrete mixtures. Moreover, the compressive strength values were increased with the increase of FA content in the mix. The highest compressive strength $(122 \mathrm{MPa})$ was recorded at 28 days at the highest FA dosage $(40 \%)$. Additionally, the water permeability depth was decreased with the increase of FA from $0 \%$ (highest permeability) to $40 \%$ (lowest permeability).

Chen et al. [24] explored the impact of autoclave curing and different FA (Class-I complying with the Chinese Standard GB/T159) dosages on the mechanical characteristics of UHPC. The FA replaced the cement by $(0 \%, 10 \%, 20 \%$ and $30 \%$ by cement weight), while the SF was utilized in an amount proportion in all mixtures (12.5\% of cement weight). Results indicated that autoclave curing is required for FA-based UHPC to obtain the best strength. The higher the FA content in the mix, the higher the pressure required in autoclave curing to acquire the highest strength. Furthermore, the increase of autoclave duration and the inclusion of FA led to reducing the porosity of the produced UHPC. Additionally, replacing the cement with FA within the range of 10-30\% enhanced the compressive and flexural strength in both appropriate autoclave and standard curing.

Gamal et al. [74] explored the characteristics of RPC incorporated FA and SF as cement replacement materials. The investigated mixtures incorporated 10\% SF and FA (ranged from $15 \%$ to $25 \%$ ). Standard and hot water curing were utilized. Results indicated that the optimum hardened properties were achieved at the replacement ratio of $30 \%(10 \% \mathrm{SF}+20 \%$ FA). Moreover, it was found that using FA alone folded lower strengths compared to that of SF+FA. 
Alsalman et al. [75] carried out an experimental study to develop economical UHPC. The impact of binder type (class-C FA and SF) and content, curing regime, mixer type and the type of aggregate were investigated. SF was utilized in two proportions (5.5\% and $20 \%$ ), while FA was utilized in the percentages of $0 \%, 20 \%, 30 \%, 40 \%$ and $50 \%$ as cement-replacing materials. Results indicated that by utilizing a binder content of $1163 \mathrm{~kg} / \mathrm{m}^{3}$ incorporated $40 \% \mathrm{FA}$ and $5.5 \%$ SF (by weight of binder), the cost of UHPC was $283 \mathrm{USD} / \mathrm{m}^{3}$, and compressive strength of $150 \mathrm{MPa}$ could be gained by applying a heat curing system.

\section{Critical Evaluation of FA-Based UHPC}

Through a review of the literature involving the utilizing of fly ashes in the production of UHPC, it is noted that in most investigations, fly ash has not been utilized as a complete substitute for silica fume, but rather has been utilized together with silica fume or other cementitious materials such as metakaolin or GGBS. A summary of the investigates that incorporated FA in the production of UHPC is presented in Table 1. It could be observed from Table 1 that limited investigations addressed the use of only FA as SCMs in UHPC. The reason for this may be due to the low pozzolanic activity of fly ashes compared to silica fume and other supplementary cementitious materials, especially at early ages [76,77]. Researchers showed that this limitation could be overcome by using accelerated curing, such as autoclave curing [73]. Despite this, replacing SF with FA was a good option in terms of reducing the cost of concrete (as FA is much cheaper than SF), as well as that FA was usually utilized in higher proportions (as seen in Table 1) than that of SF alone. This contributes to enhance the environment through the use of more proportions of industrial waste, and thus reduce the content of cement in the UHPC mixture. It can be noticed from previous work presented by Ferdosian et al. [71] that the particle size of FA utilized significantly affected the strength gain of UHPC. They recommended using FA with an average particle size of $4.48 \mu \mathrm{m}$.

As stated previously, most investigations blended FA with SF in UHPC, and the results were compared with that made with SF only. Thus, as can be seen from the previous works (Table 1), the greater the FA amount, the lower the compressive strength was gained due to the lower activity of FA related to SF. Nevertheless, the utilization of accelerated curing at the setting and hardening stages could compensate for the strength decline. There was an optimum replacement level for FA and SF that was observed in the reviewed investigations (Table 1). These levels were ranged from $15 \%$ to $40 \%$ for FA and $5 \%$ to $30 \%$ for SF. If taking into account the cost reduction of UHPC (which means lower content for SF and higher content for FA) and compressive strength no less than $150 \mathrm{MPa}$ with acceptable fluidity, combination $40 \% \mathrm{FA}+5.5 \% \mathrm{SF}$ with steam curing or $20 \% \mathrm{FA}+5 \% \mathrm{SF}$ under standard curing was considered satisfactory. 
Table 1. Investigates on the utilization of FA in the production of UHPC.

\begin{tabular}{|c|c|c|c|c|c|c|}
\hline Reference & $\mathrm{SF}(\%)$ & FA (\%) & Other Materials & Curing Methods & Tests Conducted & $\begin{array}{l}\text { Maximum Achieved } \\
\text { Compressive Strength }\end{array}$ \\
\hline$[50]$ & 35 & $10,20,40$ and 60 & GGBFS $(10 \%)$ & Autoclave curing & Compressive strength and SEM & $\begin{array}{c}248 \mathrm{MPa} \text { for mixtures with } 20 \% \mathrm{FA} \\
\text { and } 262 \mathrm{MPa} \text { for mixtures with } 10 \% \\
\mathrm{FA} \text { and } 10 \% \text { GGBFS }\end{array}$ \\
\hline$[70]$ & $15-26$ & 10,20 and 30 & GGBFS (10\%) & $\begin{array}{l}\text { Standard, autoclave and } \\
\text { steam curing }\end{array}$ & $\begin{array}{l}\text { The strengths of compressive } \\
\text { and flexural, toughness } \\
\text { and SEM }\end{array}$ & $\begin{array}{c}268 \mathrm{MPa} \text { for mixtures with } 20 \% \mathrm{FA} \\
\text { and } 270 \mathrm{MPa} \text { for mixtures with } 10 \% \\
\text { FA and } 10 \% \text { GGBFS under } \\
\text { autoclave curing. }\end{array}$ \\
\hline [10] & 30 & $20,40,60$ & - & $\begin{array}{l}\text { Standard, autoclave and } \\
\text { steam curing }\end{array}$ & $\begin{array}{l}\text { Compressive strength, splitting } \\
\text { tensile strength, flexural } \\
\text { strength, fracture energy } \\
\text { and SEM }\end{array}$ & $\begin{array}{c}270 \mathrm{MPa} \text { for mixtures with } 20 \% \mathrm{FA} \\
\text { under autoclave curing. }\end{array}$ \\
\hline [44] & $4,8,12$ and 20 & 4,8 and 12 & - & Standard water curing & Flow and compressive strength & $157 \mathrm{MPa}$ for mixtures with $60 \% \mathrm{FA}$ \\
\hline [71] & 0 and 5 & $10-35$ & MK $(0 \%$ and $2.5 \%)$ & Standard water curing & Flow and compressive strength & $153 \mathrm{MPa}$ for mixtures with $20 \% \mathrm{FA}$ \\
\hline [72] & $5,10,15$ and 20 & 30 & - & Standard water curing & $\begin{array}{l}\text { Compressive strength, } \\
\text { pore-volume and SEM }\end{array}$ & $\begin{array}{l}140 \mathrm{MPa} \text { for mixtures with } 30 \% \mathrm{FA} \\
\text { and } 20 \% \text { SF after } 365 \text { days. }\end{array}$ \\
\hline [24] & 12.5 & 10,20 and 30 & - & $\begin{array}{l}\text { Standard water and } \\
\text { autoclave curing }\end{array}$ & $\begin{array}{l}\text { The strengths of compressive } \\
\text { and flexural, mercury intrusion } \\
\text { measurement (MIP), } \\
\text { fracture toughness } \\
\text { X-ray diffraction (XRD) } \\
\text { and SEM. }\end{array}$ & $\begin{array}{l}168 \mathrm{MPa} \text { for mixtures with } 30 \% \mathrm{FA} \\
\text { after } 10 \mathrm{~h} \text { of autoclave curing. }\end{array}$ \\
\hline$[74]$ & 10 & 15,20 and 25 & - & $\begin{array}{l}\text { Standard water and hot } \\
\text { water curing }\end{array}$ & $\begin{array}{l}\text { Density, the strengths of } \\
\text { splitting tensile, flexure strength } \\
\text { and compressive strength; and } \\
\text { Slump flow }\end{array}$ & 93.33 MPa for mixtures with $20 \% \mathrm{FA}$ \\
\hline [75] & 5.5 and 20 & $20,30,40$ and 50 & - & Heat-curing & Compressive strength & $\begin{array}{l}148 \mathrm{MPa} \text { for mixture with } 40 \% \mathrm{FA} \text { and } \\
5.5 \% \mathrm{SF} \text { after } 28 \text { days of heat curing at } \\
90^{\circ} \mathrm{C} \text {. }\end{array}$ \\
\hline
\end{tabular}


Furthermore, most previous research utilized Class-C FA as a substitute for cement together with SF. This may be because Class-C has more calcium content than that of Class-F [78,79] which means higher strength gain at early ages. Despite that, extensive experimental investigations should be performed to compare the performance of the two classes in UHPC production, especially at different curing systems (standard and accelerated curing), as well as at early and later ages.

\subsection{Utilization of GGBS in the Production of UHPC}

GGBS is one of the known viable alternatives materials to cement in different applications. GGBS is a by-product material of iron or steel extracted from blast furnaces in water or steam. After that, it will be dried and ground in a rotating ball mill into a very fine powder of GGBS [42]. The GGBS has two different phases: the first one is the glassy phase, which is responsible for the cementitious characteristics of GGBS, while the second phase is the crystalline phase, which is responsible for hydration [80]. GGBS has many advantages relative to cement, such as: enhancing durability; improving workability; and reducing the risk of damaging internal reactions such as the Alkali-Silica Reaction (ASR) [42]. As GGBS has a very finely glassy powder, it increases the bond between particles and minimizes the permeability of concrete, which makes the concrete more resistant to chloride ingress, and protects the internal reinforcement from corrosion [81]. The following are investigations that utilized GGBS in the production of UHPC.

Yaz1c1 et al. [82] researched the mechanical characteristics of RPC incorporated with a high volume fraction of GGBS $(20 \%, 40 \%$ and $60 \%)$ as a substitution of cement. The results were compared with the control mixture, which was made with $30 \%$ SF by weight of cement (about 23\% of the total binder). Results indicated that compressive strength of over $250 \mathrm{MPa}$ was produced for GGBS-based RPC after autoclaving. Moreover, the compressive strength might reach up to $400 \mathrm{MPa}$ when pressure was applied during the setting and hardening stages. Furthermore, it was revealed that SF amount could be decreased with the increase of GGBS content in the mix, which consequently led to reducing the superplasticizer demand significantly.

Ghafari et al. [83] investigated the use of GGBS as SF replacement to reduce the autogenous shrinkage of UHPC. The reference mixture was designed to include $24 \%$ SF by weight of cement. The other mixtures included the full replacement of SF with GGBS. Results indicated that GGBS-based mixtures revealed comparable mechanical characteristics and volume of permeable pores as that for the reference mixture (containing SF). The highest compressive strength was obtained after combining GGBS and SF under ambient temperature (the combination percentage was approximately 1.2). Additionally, results showed GGBS could reduce the autogenous shrinkage of UHPC, as a result of their role in refining the pore structure.

Wang et al. [84] investigated the strength and fluidity of UHPC made from SF (10\%), GGBS (20-40\%) and limestone powder (LP) (20-40\%) as cement replacement materials. Results indicated that combining 50\% cement, 10\% SF, 20\% GGBS and 20\% LP, together with a water/binder ratio of 0.16 and an adequate amount of superplasticizer, were necessary to prepare successful UHPC with a maximum slump of $268 \mathrm{~mm}$ and compressive strength of 175.8 $\mathrm{MPa}$ and 182.9 $\mathrm{MPa}$ at 90 and 365 days, respectively.

Gupta [85] developed UHPC that included a blend of GGBS and SF in different proportions as a replacement of cement. GGBS was utilized in three proportions, 40\%, $60 \%$ and $80 \%$, while SF was utilized in proportions of $0 \%, 10 \%, 15 \%$ and $20 \%$. Three fineness grades were utilized for GGBS (403, 605 and $\left.797 \mathrm{~m}^{2} / \mathrm{kg}\right)$ and SF $(19,000,25,000$ and $30,000 \mathrm{~m}^{2} / \mathrm{kg}$ ). The study looked to develop UHPC in which the cement could replace with a high content of GGBS and SF combinations. Results indicated that the combination of these two materials enhanced the early and later strength of UHPC by $10 \%$ and 17\%, respectively, compared to the control mix (without replacement). Furthermore, it had also been found that although the strength increased with an increase in the fineness of the pozzolanic materials, this was not necessarily true in the case of mixing two pozzolanic 
materials. Where it was found that when the highest fineness of SF and GGBS was utilized, the strength was reduced from its maximum value by about $13 \%$.

Randl et al. [86] investigated the impact of using fine GGBS and extra-fine GGBS on the workability and mechanical performance of UHPC. During this investigation, the cement was replaced by $45 \%$ of fine GGBS or extra-fine GGBS. The reference (without GGBS) and GGBS mixtures contained $17 \%$ SF. The results indicated that mixtures incorporated fine GGBS or extra-fine GGBS resulted in a higher slump flow diameter, while it caused a slight reduction in the compressive strength by about $16 \%$ and $2 \%$, respectively. Additionally, the authors reported that replacing the cement with GGBS could significantly enhance the durability and increase the lifetime of UHPC.

Kim et al. [87] sought to produce UHPC with a high compressive strength reach of $150 \mathrm{MPa}$ and high flowability using industrial GGBS. The GGBS was utilized to partially replace the cement with four replacement levels $(0 \%, 15 \%, 30 \%$ and $50 \%)$. SF content in all mixtures was $25 \%$ (as cement replacement material). It was found that the flowability increased with increasing the replacement of cement with GGBS. The results also showed that increasing the GGBS content resulted in lower compressive strength relative to the control mixture. The maximum loss in the compressive strength was $10.9 \%$ reported for the mixture with 50\% GGBS. Additionally, it was found that increasing the GGBS content resulted in the lower strength development of the UHPC.

Gupta [88] explored the impact of fineness and content of GGBS on the workability, strength and durability of UHPC. GGBS of three different specific surface areas, $400 \mathrm{~m}^{2} / \mathrm{kg}$, $556 \mathrm{~m}^{2} / \mathrm{kg}$ and $750 \mathrm{~m}^{2} / \mathrm{kg}$, were added at two different cement replacement percentages: $20 \%$ and $60 \%$ by weight. A flow table test was conducted to study the impact of fineness and content of GGBS on the workability of UHPC. Compressive and flexural strength tests have been conducted to study the rate of strength development at different ages of UHPC, while water penetration and chloride migration tests were conducted to estimate the durability of UHPC. The results from the flow table test indicated that increasing the content of GGBS with specific surface areas of $400 \mathrm{~m}^{2} / \mathrm{kg}$ and $556 \mathrm{~m}^{2} / \mathrm{kg}$ enhanced the flowability of the UHPC, while the GGBS with specific surface areas of $750 \mathrm{~m}^{2} / \mathrm{kg}$ resulted in reduced flowability relative to the control mixture made with $100 \%$ cement. The results also indicated that the highest compressive strength and flexural strength were achieved for the GGBS, with specific surface areas of $556 \mathrm{~m}^{2} / \mathrm{kg}$ at both percentages of replacement. The results of the durability tests indicated that the resistance of water penetration of the UHPC enhanced with increasing the fineness of the GGBS, as finer particles tend to reduce the porosity of the matrix. Additionally, the results from the chloride migration test indicated that UHPC incorporated GGBS with the fineness of $556 \mathrm{~m}^{2} / \mathrm{kg}$ has very high to extremely high chloride migration after 28 days and 90 days of curing, respectively, for both levels of replacement. Finally, the author concluded that using 20\% GGBS fineness of $556 \mathrm{~m}^{2} / \mathrm{kg}$ was ideal to enhance the early and long-term characteristics of UHPC.

Wu et al. [89] carried out an experimental study to investigate in flexural characteristics of UHPC with GGBS under various curing systems (normal, hot water and steam curing). Each material was utilized as cement replacement by $20 \%, 40 \%$ and $60 \%$. SF was utilized together with GGBS, as well as in the control mixture (without GGBS) in a proportion of $25 \%$ of the total binder. Results indicated that the higher the GGBS content in the mix, the higher the flowability. In terms of curing type, it was found that GGBS had a limited, or even negative impact on the compressive strength of UHPC. Moreover, for flexural strength, optimum content should be utilized as $40 \%$ GGBS. Beyond that dosage, the flexural characteristics, toughness and strength could be dropped. Furthermore, though the accelerated curing utilized increased the compressive and flexural strengths properties, nevertheless, at optimum content of GGBS, comparable flexural strength and toughness with that of standard (normal) curing were recorded at 28 days. Thus, the authors concluded that when an appropriate content of GGBS was utilized, the standard curing was adequate to produce UHPC with satisfactory flexural characteristics. 
Ganesh and Murthy [90] discovered the durability characteristics and tensile behavior of UHPC using GGBS in proportions of $0 \%, 20 \%, 40 \%, 60 \%$ and $80 \%$ (by weight of cement) as cement replacement material. The control (without GGBS) and GGBS-based mixtures incorporated $15 \%$ SF by weight of cement. Two curing regimes were taken into account: standard and elevated temp. Flowability, compressive strength, split tensile strengths, fracture, direct tensile strength and durability characteristics (rapid chloride penetration test and water sorptivity) were examined. Results showed that the fluidity of UHPC was enhanced by adding GGBS as a result of its particle surface characteristics and better dispersion. Moreover, the hardened characteristics of UHPC were significantly enhanced up to $40 \%$ GGBS (as cement replacement) under standard curing, while the elevated temp enhanced its performance up to $60 \%$ replacement percentage.

Nadiger et al. [91] investigated the impact of replacing cement with SF or ultrafine GGBS. The replacement level for each material was ranged from $0 \%$ to $15 \%$. GGBS was utilized to replace SF for its economical availability. Results indicated that GGBS had the same characteristics for SF in terms of mixing and workability, nevertheless, the strength was reduced by $5.2 \%$ compared to that of the SF replacement. Moreover, the cylinder compressive strength, split tensile strength and flexural strength were enhanced by $40-50 \%$ after the addition of GGBS compared to the control mix (without replacement).

\section{Critical Evaluation GGBS-Based UHPC}

A summary of the investigates that incorporated GGBS in the production of UHPC is presented in Table 2. Regarding the above literature, it can be seen that the fineness of GGBS had an important impact on the flowability and hardened characteristics of UHPC. The increase of GGBS fineness (especially when combined with SF) up to a certain level enhanced the characteristics of UHPC, beyond which the enhancement was dropped. This also means there is an optimum fineness for GGBS when present together with SF in UHPC. This characteristic of GGBS was noted when it was utilized alone [88], or even combined with SF [85] in the production of UHPC. 
Table 2. Investigates on the utilization of GGBS in the production of UHPC.

\begin{tabular}{|c|c|c|c|c|c|c|}
\hline Reference & SF (\%) & GGBS (\%) & Other Materials & Curing Methods & Tests Conducted & $\begin{array}{l}\text { Maximum Achieved } \\
\text { Compressive Strength }\end{array}$ \\
\hline [82] & - & 20,40 and 60 & - & $\begin{array}{l}\text { Standard, autoclave and } \\
\text { steam curing }\end{array}$ & $\begin{array}{l}\text { Flexural strength, compressive } \\
\text { strength, toughness, fracture } \\
\text { energy and SEM }\end{array}$ & $\begin{array}{l}378 \mathrm{MPa} \text { for mixtures with } 40 \% \text { GGBS after } \\
\text { the application of } 30 \mathrm{MPa} \text { pressure for } 8 \mathrm{~h}\end{array}$ \\
\hline [83] & 0 and 11.5 & 10 and 23 & - & $\begin{array}{l}\text { Standard and steam } \\
\text { curing }\end{array}$ & $\begin{array}{c}\text { Compressive strength, flexural } \\
\text { strength, autogenous shrinkage, } \\
\text { Water absorption and volume of } \\
\text { permeable voids }\end{array}$ & $\begin{array}{l}162 \mathrm{MPa} \text { for mixtures with } 23 \% \text { GGBS and } \\
11.5 \% \mathrm{SF} \text { under steam curing } 90^{\circ} \mathrm{C} \text {. }\end{array}$ \\
\hline [84] & 10 & 20 and 40 & $\begin{array}{l}\text { Limestone powder } \\
(0 \%, 20 \% \text { and } 40 \%)\end{array}$ & Standard water curing & $\begin{array}{l}\text { Fluidity, compressive strength } \\
\text { and SEM }\end{array}$ & $\begin{array}{c}178 \mathrm{MPa} \text { for mixtures with } 20 \% \text { GGBS and } \\
10 \% \text { SF and } 182.9 \mathrm{MPa} \text { for mixtures with } \\
20 \% \text { GGBS, } 10 \% \mathrm{SF} \text { and } 20 \% \text { limestone } \\
\text { powder after } 365 \text { days of curing }\end{array}$ \\
\hline [85] & $0,10,15$ and 20 & 40,60 and 80 & - & $\begin{array}{l}\text { Sealed curing, air curing } \\
\text { and moist curing }\end{array}$ & $\begin{array}{l}\text { Compressive strength and } \\
\text { flexural strength }\end{array}$ & $\begin{array}{c}165 \mathrm{MPa} \text { for mixtures with } 60 \% \text { GGBS and } \\
181 \mathrm{MPa} \text { for mixtures with } 60 \% \text { GGBS and } \\
10 \% \text { SF after } 90 \text { days of curing }\end{array}$ \\
\hline [86] & 17 & 45 & - & Standard water curing & Flow and compressive strength & $\begin{array}{l}163.5 \mathrm{MPa} \text { for mixtures with } 45 \% \text { extra } \\
\text { fine GGBS }\end{array}$ \\
\hline [87] & 25 & 15,30 and 50 & - & Standard water curing & Flow and compressive strength & $\begin{array}{l}160 \mathrm{MPa} \text { for mixtures with } 15 \% \text { GGBS after } \\
28 \text { days of curing }\end{array}$ \\
\hline [88] & - & 20 and 60 & - & Standard water curing & $\begin{array}{l}\text { Flow, compressive strength, } \\
\text { flexural strength, water } \\
\text { penetration and } \\
\text { chloride migration }\end{array}$ & $\begin{array}{l}146 \mathrm{MPa} \text { for mixtures with } 20 \% \text { GGBS after } \\
90 \text { days of curing }\end{array}$ \\
\hline [89] & 25 & 20,40 and 60 & - & $\begin{array}{l}\text { Standard water, hot } \\
\text { water and steam curing }\end{array}$ & $\begin{array}{l}\text { Flow, compressive strength, } \\
\text { flexural strength and toughness }\end{array}$ & $\begin{array}{l}182 \mathrm{MPa} \text { for mixtures with } 20 \% \text { GGBS } \\
\text { using hot water curing and steam curing. }\end{array}$ \\
\hline$[90]$ & 15 & $20,40,60$ and 80 & - & $\begin{array}{l}\text { Standard water and } \\
\text { oven curing }\end{array}$ & $\begin{array}{l}\text { Flow, compressive } \\
\text { strength, tensile strength, fracture, } \\
\text { rapid chloride penetration, water } \\
\text { sorptivity and SEM. }\end{array}$ & $\begin{array}{c}167.95 \mathrm{MPa} \text { for mixtures with } 40 \% \text { GGBS } \\
\text { under oven curing at } 150{ }^{\circ} \mathrm{C} \text {. }\end{array}$ \\
\hline [91] & - & 5,10 and 15 & - & $\begin{array}{l}\text { Standard water curing, } \\
\text { preheat curing and } \\
\text { post-heat curing }\end{array}$ & $\begin{array}{l}\text { Workability, compressive strength, } \\
\text { split tensile strength, flexure } \\
\text { strength and XRD }\end{array}$ & $\begin{array}{l}165 \mathrm{MPa} \text { for mixture with } 10 \% \text { GGBS after } \\
\text { post-heat curing }\end{array}$ \\
\hline
\end{tabular}


According to Table 2, a wide range of replacements ( $0 \%$ to $80 \%$ ) of cement with GGBS was found for making UHPC in previous investigations. GGBS in most of these investigates was combined with SF. This may be attributed to the slow hydration rate of GGBS, which leads to slow strength enhancement [92,93]. This claim is supported by Beushausen's [94] findings, which stated that the GGBS-based mortar had a longer setting time and lower early heat and strength development than conventional mortar (without GGBS). Thus, it is believed that GGBS was combined with SF to overcome this shortage.

On the other hand, it can be observed from previous investigations that there is a fluctuation about the best ratios for replacing cement with GGBS; where some researchers recommended $20 \%$ [84,88], others said $40 \%$ [89,90] (by weight of cement). A replacement level of $60 \%$ was also considered in previous works [85]. This difference among researchers in the proportions of substitution cement with GGBS may be caused by the difference in the pozzolanic activity of the SCMs utilized and their chemical composition, as well as their differences in fineness. Additionally, the percentage of combinations between GGBS and SF also differs. As a summary, and regardless of that, to choose a practical percentage, the combination ratio of GGBS/SF will be adopted as a criterion for choosing the appropriate percentage for both substances. Accordingly, regarding the above literature (Table 2), the suitable GGBS/SF ratios for producing UHPC without harming (or even improving) its fresh and hardened characteristics are within the range 1.2 to 2 .

The impact of curing type (standard, hot water, steam and autoclave) on GGBS-based UHPC was also discussed in the above literature. The accelerated curing could increase the replacement level of GGBS, as revealed by Ganesh and Murthy [90]. On the other hand, according to $\mathrm{Wu}$ et al. [89], although the accelerated curing had a role in increasing the strength of UHPC, to reduce the cost of production and energy conservation, when suitable proportions of materials and an adequate amount of superplasticizer were utilized, the standard (normal) curing is considered satisfactory for GGBS-based UHPC.

\subsection{Utilization of MK in the Production of UHPC}

Metakaolin is a pozzolanic material developed from the heat treatment of one of the most common substances contained, a natural form of clay named kaolin. Kaolin is a fine powder historically utilized by the Chinese for the manufacture of porcelain and coating material for papers. [95]. $\mathrm{MK}$ is typically rich with $\mathrm{SiO}_{2}$ and $\mathrm{Al}_{2} \mathrm{O}_{3}$, along with other oxides existing in minor amounts such as $\mathrm{MgO}, \mathrm{CaO}, \mathrm{TiO}_{2}$ and $\mathrm{Fe}_{2} \mathrm{O}_{3}$ [96]. MK particles typically have a diameter of 0.5 to 5.0 microns, which is smaller than cement particles and greater than silica fume (SF) particles. In general, various forms of MK are based on the sources of their kaolin clay and the applied heat remediation. MK is a cement additive that has a positive impact on the efficiency of mortars and concrete. The following are investigations that utilized MK in the production of UHPC.

Rougeau and Borys [97] utilized MK in the production of UHPC. The ultrafine materials / cement ratio was $20 \%$ (about $16.7 \%$ of the total binder weight). Fluidity, pore structure, compressive and flexural strengths and water absorption tests were performed. Results indicated that SF showed better performance relative to MK. Moreover, MK awarded white surface color which was considered as an important advantage compared to the dark-grey surface color of SF concrete.

Staquet and Espion [98] utilized a combination of SF and MK in the production of UHPC to minimize the autogenous shrinkage. Two curing temps were applied after two days of casting: $20^{\circ} \mathrm{C}$ and $42{ }^{\circ} \mathrm{C}$. Results indicated that at $20^{\circ} \mathrm{C}$ curing, the MK-based UHPC showed lower autogenous shrinkage than other mixes. On the other hand, the UHPC at $42{ }^{\circ} \mathrm{C}$ revealed negligible total shrinkage compared to other mix proportions.

Tafraoui [99] investigated the use of MK instead of SF in the production of UHPC to overcome the high cost of SF, its color and the lack of availability, as well as the availability of kaolinite in most countries. The MK was utilized with $20 \%$ of the total binder. Results indicated that the weight-by-weight replacing of SF with MK imparted an equivalent mechanical performance for UHPC. Nevertheless, the mixing time was increased slightly 
for MK-based UHPC. Additionally, heat treatment had a major role in enhancing the compressive and flexural strengths of the UHPC.

An experimental and theoretical (using ANSYS computer program) study was carried out by Al-Azzawi [100] to understand the behavior of UHPC made with 15\% MK. Experimental results indicated that lower compressive strengths values were achieved for UHPC made with MK compared with that made with SF. Additionally, for compressive stress-strain relationships, results demonstrated that the stress of UHPC made with MK was lower than that of SF at any given strain.

Rabehi et al. [48] explored the impact of three kinds of Algerian calcined clays (metakaolin) on the performance of UHPC. The three types of MK were calcined silt of dams, incinerated waste paper sludge and calcined clay of Djbel Debbagh quality 3 (available in eastern Algeria). Each material was utilized in the percentage of $25 \%$ of the total binder. Results indicated that the substitution of SF by Djbel Debbagh MK led to a negligible decrease in compressive strengths $(2.3 \%)$ and a slight increase in flexural strengths $(13 \%)$. Nevertheless, other additions affected the compressive strengths unfavorably with a slight decrease in flexural strengths. It was concluded from that study that the Djbel Debbagh MK could be utilized as pozzolanic material in the production of UHPC.

In a related study, Amanjean and Vidal [101] replaced the SF with MK to produce low-cost UHPC. Two cement replacement levels for MK $(20 \%$ and $24 \%$ of the total binder weight) were utilized. Results indicated that the MK mixture showed a slight reduction in compressive strengths (5\%) than that of the reference mixture, but nevertheless the material cost of UHPC per cubic meter was reduced by $10 \%$. The packing density results revealed that the optimum MK to cement ratio was 0.3 , instead of 0.25 , for the SF to cement ratio.

$\mathrm{Li}$ [102] made an experimental study to investigate and predict the paste fraction drying shrinkage of UHPC having ternary and binary combinations of MK, FA and cement. Results indicated that the MK-cement binary combination paste had lower drying shrinkage than the paste produced with pure cement.

Tafraoui et al. [103] explored the durability performance of UHPC containing MK instead of SF in the proportion of $25 \%$ by cement weight. Results indicated that the accelerated carbonation, the migration of the chloride ions and the permeability of oxygen diffusion assured good durability characteristics of UHPC-incorporated MK. Furthermore, these durability tests did not permit discrimination from different pozzolanic additions.

Huang et al. [104] replaced the silica fume in UHPC with two calcined clay grades (MK with 95\% kaolinite and calcined clay with 79\% kaolinite) to explore their impact on the hydration and microstructure characteristics of the resultant UHPC. The cement had already been substituted (by volume) with $54 \%$ of limestone with the same particle size distribution. The calcined clay content was $9 \%$ by weight of the total binder. Results of MK-based UHPC showed a 10.4\% reduction in compressive strengths compared to SF mix at 28 days. While calcined clay with $79 \%$ kaolinite reduced the compressive strengths by $2.3 \%$ at the same age. It was also found that the cement hydration was hindered in calcined clay-based mixtures in comparison to SF mixture due to the less free water obtainable for cement hydration, especially for mixtures containing MK. Due to the reduction of free water, the portlandite formation was also reduced in calcined clay mixtures compared to the SF mix. Additionally, results demonstrated that though that the replacing of SF with calcined clay refined the critical radius pores in UHPC, the compressive strengths did not enhance.

Šeps et al. [105] explored the impact of substitution cement with metakaolin on the mechanical-physical characteristics of UHPC. MK material replaced the cement by $10 \%$, $20 \%$ and $30 \%$. Results indicated that compressive strengths increased as the MK amount increased in the mixture up to $20 \%$, and it was then decreased lower than that of the control mixture. Nevertheless, flexure strengths values were decreased with the increase of MK percentage up to $20 \%$. After that (at 30\% MK), the flexure strengths was enhanced. Density results showed that $20 \%$ of MK increased the density compared to the reference 
mixture. Contrarily, for $10 \%$ and $30 \% \mathrm{MK}$, the density values were lower than that of the free-substitution mix.

\section{Critical Evaluation of MK-Based UHPC}

A summary of the investigates that incorporated MK in the production of UHPC is presented in Table 3. Obviously, from a literature survey, it can be seen that the number of investigates that employed MK instead of SF in the manufacturing of UHPC was limited; this may be due to the fluctuation of the results of the characteristics of UHPC containing MK compared to SF as can be seen in Table 3. This fluctuation in MK concretes can be attributed to the difference in the characteristics of the material utilized such as fineness, particle size distribution, chemical composition, pozzolanic activity and the method of production of MK (for example calcined temp and soaking duration). Additionally, the workability characteristics (which are affected by MK water demand) of the fresh UHPC mixtures which inspire the compactness, and consequently the density of the interfacial transition zone (ITZ) of UHPC has an important role. Furthermore, the percentage of substitution of cement with MK in the mixture impacts its behavior in the produced UHPC. 
Table 3. Investigates on the utilization of MK in the production of UHPC.

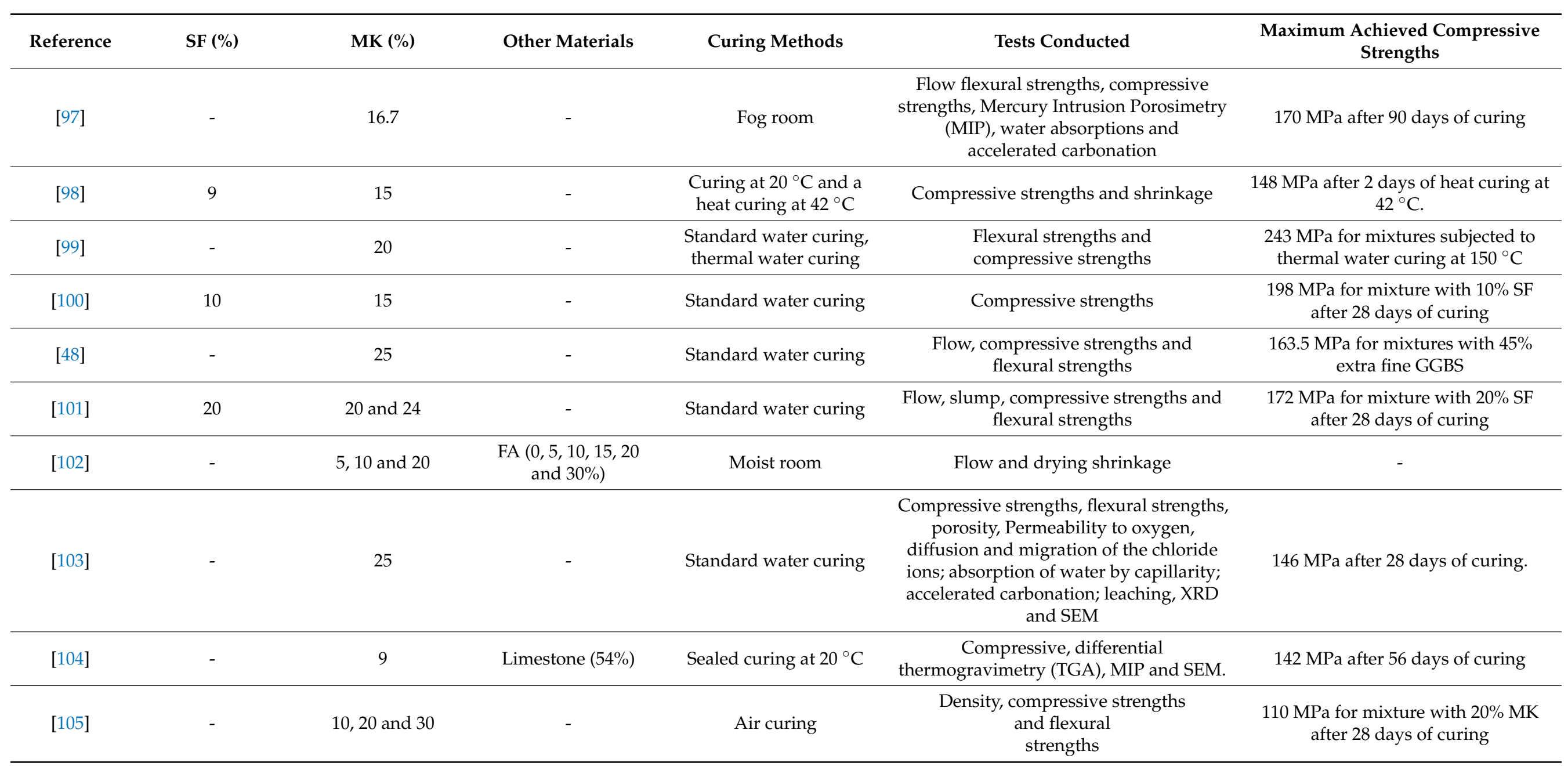


It can be seen from the previous works that when SF was compared with MK, SF had better performance than MK in most investigations [48,97,100,101,104], while only one piece of research showed that MK had an equivalent performance to SF [99]. The compressive strengths value (which is considered the essential characteristic of UHPC) was the main comparison parameter in most investigations between SF- and MK (as replacement of cement)-based UHPC. Nevertheless, as stated previously, one of the significant aims for using MK instead of SF in the production of UHPC is to reduce the cost of materials. Additionally, the cement content in UHPC may reached as high as $800-1000 \mathrm{~kg} / \mathrm{m}^{3}[37,70]$. Furthermore, It was reported that the cost of 1 tonne of SF in the USA (for example) is about US\$879, while it is about US\$500 for MK [106]. Accordingly, the "compressive

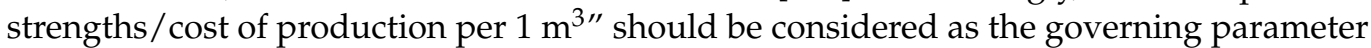
for comparison between SF and MK, rather than just the compressive strengths. Moreover, by using MK, the resultant concrete achieved the ultra-high performance of UHPC with compressive strengths reaching more than $140 \mathrm{MPa}$ at 28 days [103]. Otherwise, it is known that the packing impact in the UHPC matrix is a remarkable issue. Furthermore, as reported by Amanjean and Vidal [101], the packing density of MK/cement was 0.3, compared to 0.25 for SF/cement. Therefore, the comparison of equal weight between the two materials (SF and MK) is not quite true due to the packing density impact. The kaolinite content in the calcined clay had also an essential parameter. As demonstrated by Huang et al. [104], the calcined clay with a lower kaolinite percentage had better performance than that of those with the higher percentages.

According to Table 3, the percentages of substitution for MK ranged from 5 to $30 \%$ of the cement weight. The average substitution level of MK was $25 \%$ of the cement weight. This proportion was based on the performance comparison with SF. Nevertheless, if the MK performance was compared with the neat cement (without replacement), the MK replacement level should not exceed $20 \%$ of the cement weight. Nevertheless, practically, the UHPC is included cement replacing (with SCMs) in its production to reduce the high content of cement. Thus, the substitution of cement with $25 \%$ of MK is suitable to obtain UHPC with an equivalent or a slight reduction in mechanical performance compared to SF.

\subsection{Utilization of RHA in the Production of UHPC}

Rice Husk Ashes (RHA) is a waste material produced from the burning process of rice husk, which is utilized as fuel in the boilers for processing of paddy or for power generation. RHA is a super-pozzolanic material due to its high silica content $(85 \%$ to 90\%) [107], and thus it could be utilized as an alternative to SF in the production of UHPC. The following are investigations that utilized MK in the production of UHPC.

Tuan et al. [108] explored the impact of RHA on the autogenous shrinkage of UHPC. The compressive strengths and microstructure were also investigated. RHA replaced the cement in two ratios (10\% and $20 \%$ ), and its performance compared with the control mix (without replacement) and others made with $10 \%$ and $20 \%$ SF as cement substitution. The particle size ranges of the RHA were $5.6 \mu \mathrm{m}$ to $9.0 \mu \mathrm{m}$. Results indicated that the autogenous shrinkage dramatically declined at the replacement ratio of $20 \%$ of RHA, and was even eliminated at later ages. The authors attributed this behavior to the pozzolanic reaction, pore refinement and internal curing provided by RHA. Moreover, at this replacement ratio $(20 \%)$, the compressive strengths development was more pronounced than that of SF.

Tuan et al. [109] explored the hydration and microstructure of UHPC-utilizing RHA as a cement replacement. The results were compared with the control mixture (without replacement) and SF containing mixture. RHA and SF replaced the cement by $20 \%$. Results indicated that the RHA enhanced the cement hydration degree at later ages. The water uptake of the porous structure of RHA led to internal curing of the RHA-based mixture. Furthermore, it was found that at seven days, the compressive strengths of the RHA mixture was higher than that for control and SF mixtures. Additionally, RHA refined the pore structure and decreased the calcium hydroxide content of UHPC, but was less important than SF. 
Tuan et al. [2] utilized RHA as a cement substitution in the production of UHPC. It was stated that if RHA was utilized in percentages less than $30 \%$, it did not significantly decrease the compressive strengths compared to that of SF. Additionally, in comparison to SF, the fineness of RHA played a remarkable function in the compressive strength development of UHPC. The compressive strengths development of RHA-based UHPC was higher than that for SF. The optimum average particle size of RHA was found to be $5.6 \mu \mathrm{m}$. Moreover, it was revealed that the combination of $10 \%$ SF and $10 \%$ RHA (the optimum synergic impact) imparted higher compressive strengths than that for the control specimen (without RHA or SF).

Tian et al. [110] explored the characteristics of UHPC which was made by replacing the SF (partially or completely) with low-temp rice husk ashes (LRHA). SF or L-RHA replaced the cement within the range of $10 \%$ to $30 \%$. Mixtures contained SF+ L-RHA combinations were also executed. Results indicated that the adsorption capacity and pozzolanic activity of L-RHA were more than that for SF as a result of its amorphous $\mathrm{SiO}_{2}$ and porosity. Moreover, the compressive strength was increased by the filling impact, as well as the hydration rate for L-RHA, compared to only the filling impact for SF. Furthermore, the blending of L-RHA and SF gave higher compressive strengths compared to that of each material alone.

Van et al. [111] explored the performance of UHPC mixtures made with RHA with and without GGBS and compared them with those made with SF. The autogenous shrinkage, compressive strengths and Portrandite content were tested. Results indicated that at the same superplasticizer dosage and water content, the RHA-based UHPC had comparable workability and compressive strengths to that of SF. The UHPC autogenous shrinkage was lessened after using RHA. The combination of RHA and GGBS enhanced the aforementioned characteristics of UHPC. It was concluded from that study that RHA could act as an internal curing agent, as well as highly pozzolanic material in UHPC.

Asteray et al. [112] conducted an experimental investigation to explore the impact of full replacement of SF in RPC by RHA-waste glass powder (WGP) combinations. A mixture containing $25 \%$ SF as cement replacement material was utilized as control. The RHA-WGP combinations (by weight of SF) were $75-25 \%, 50-50 \%$ and $20-80 \%$, respectively. The quartz powder in RPC was fully replaced with waste ceramic powder. The compressive strengths at 7, 14 and 28 days were examined using standard curing. Findings showed that the best compressive strengths (with an enhancement ratio of 9.5\% compared to the control mixture) was achieved after replacing the SF with 80\% RHA and 20\% WGP.

Huang et al. [113] conducted experimental work to investigate the impact of RHA on the strengths and permeability of UHPC. The RHA was prepared by burning rice husk at $500{ }^{\circ} \mathrm{C}$ for $2 \mathrm{~h}$, then was utilized as SF replacement in different percentages $(0 \%$ to $100 \%$ by weight of SF). The reference mixture incorporated $23 \%$ SF as a cement replacement material. Results indicated that the UHPC fluidity was decreased while the entrapped air was raised with the increase of RHA content. The best enhancement in compressive strengths, impermeability and pore refinement was achieved at the $2 / 3$ replacement ratio (SF/RHA). At this ratio, the compressive strengths values were enhanced by $9.76 \%, 14.50 \%$, $10.02 \%$ at 3,28 and 120 days respectively.

Amin [114] investigated the characteristics of UHPC made with RHA alone or mixed with either SF or GGBS as a replacement of cement. Flow, mechanical and permeability characteristics of UHPC were observed. It was found out that the workability of UHPC was increased with the increase of RHA content in the mix. Findings indicated that regarding all hardened tests performed in that study, the 20\% replacement level was the optimum percentage for RHA. Additionally, results showed that the RHA has lower pozzolanic activity than SF.

Vigneshwari et al. [115] investigated the potential use of thermally treated RHA as SF replacement in the manufacturing of RPC. RHA was produced by burning it under different controlled temps $\left(550{ }^{\circ} \mathrm{C}\right.$ to $\left.700{ }^{\circ} \mathrm{C}\right)$ and durations ( $1 \mathrm{~h}$ to $4 \mathrm{~h}$ ). RHA, which had higher silica content and an amorphous state, was chosen to be utilized in RPC. XRD 
results showed that all prepared RHA was in an amorphous state. Finally, RHA with $89.9 \%$ silica content which was prepared under $600^{\circ} \mathrm{C}$ for 3 hrs was chosen to be utilized in UHPC. One control mixture incorporated $24 \%$ SF as cement replacement and five mixtures in which the SF was partially replaced with $10 \%, 20 \%, 30 \%, 40 \%$ and 50\% RHA. Results indicated that higher splitting tensile, flexural and compressive strengths were achieved at $30 \%$ replacement of SF with RHA. After this ratio, the strengths were reduced but remained greater than that for the control mixture. The porosity and chloride penetration, as well as resistance to an aggressive environment, were enhanced with the increase of replacement of SF with RHA. Moreover, results demonstrated that RHA could be utilized as an alternative to SF in RPC as a result of its satisfactory mechanical and durability characteristics under standard and steam curing.

Kang et al. [116] prepared and utilized RHA as a partial replacement of SF in UHPC under standard curing (without heating). The results compared with the control mix which contained $20 \%$ SF as cement replacement. Results indicated that RHA with an amorphous silica content of $92 \%$ at a burning temp of $650{ }^{\circ} \mathrm{C}$ for $1 \mathrm{~h}$ was obtained. UHPC results revealed that an outstanding strength of about $190 \mathrm{MPa}$ at 91 days was achieved under standard curing. The authors explained that prominent strengths to the additional water provided by the porous structure of RHA (internal curing) promoted the hydration process for long period, its pozzolanic reactivity and the reduction of the capillary pores in the produced UHPC.

\section{Critical Evaluation of RHA-Based UHPC}

A summary of the investigates that incorporated RHA in the production of UHPC is presented in Table 4. It can be noticed from the above literature that RHA is considered as a promising alternative material for SF in the production of UHPC, as it had a similar chemical composition (amorphous silica with silica content might exceed 90\%), high pozzolanic activity and better performance than SF at later stages. The porous structure of RHA gave it the ability to uptake water, which will be provided for prolonging hydration at later stages. The particle size of RHA had a remarkable impact on the characteristics of UHPC, as was revealed previously $[2,108]$ that RHA with a particle size of 5.6 is suitable for UHPC. It was noted that the silica content of the prepared RHA is affected by the burning temp and soaking period. Some investigations indicated that burning of rice husk at $600{ }^{\circ} \mathrm{C}$ for 3 hrs could produce a high-purity RHA (silica content is about $90 \%$ ) with amorphous silica, while others stated that it could be produced at a higher temperature $\left(650^{\circ} \mathrm{C}\right)$ and lower burning time $(1 \mathrm{~h})$ with higher silica content $(92 \%)$. It is believed that the use of local materials and different chemical compositions of the rice husk utilized explained these differences. 
Table 4. Investigates on the utilization of RHA in the production of UHPC.

\begin{tabular}{|c|c|c|c|c|c|c|}
\hline Reference & $\mathrm{SF}(\%)$ & RHA (\%) & Other Materials & Curing Methods & Tests Conducted & $\begin{array}{l}\text { Maximum Achieved } \\
\text { Compressive Strengths }\end{array}$ \\
\hline [108] & - & 10 and 20 & - & Fog room & $\begin{array}{l}\text { Compressive strengths, autogenous } \\
\text { shrinkage, SEM, MIP and TGA }\end{array}$ & $\begin{array}{l}185 \mathrm{MPa} \text { for mixtures with } 20 \% \text { RHA after } \\
91 \text { days of curing }\end{array}$ \\
\hline [109] & - & 20 & - & Fog room & $\begin{array}{c}\text { Compressive strengths, SEM, MIP } \\
\text { and TGA }\end{array}$ & $\begin{array}{l}185 \mathrm{MPa} \text { for mixtures with } 20 \% \text { RHA after } \\
\qquad 91 \text { days of curing }\end{array}$ \\
\hline [2] & $0,5,10$ and 15 & $\begin{array}{c}5,10,15,20 \text { and } \\
30\end{array}$ & - & Fog room & $\begin{array}{l}\text { Flow, compressive strengths, } \\
\text { autogenous shrinkage, Portrandite } \\
\text { content, SEM and XRD. }\end{array}$ & $\begin{array}{c}210 \mathrm{MPa} \text { for mixtures with } 10 \% \text { RHA and } \\
10 \% \text { SF after } 91 \text { days of curing }\end{array}$ \\
\hline [110] & 10,20 and 30 & 10,20 and 30 & - & Standard water curing & $\begin{array}{l}\text { Pozzolanic activity, adsorption } \\
\text { capacity and compressive strengths }\end{array}$ & $\begin{array}{c}180 \mathrm{MPa} \text { for mixtures with } 10 \% \text { RHA and } \\
10 \% \text { SF after } 28 \text { days of curing }\end{array}$ \\
\hline [111] & - & 17 & $\begin{array}{c}\text { GGBS }(0 \% \text { and } \\
20 \%)\end{array}$ & $\begin{array}{l}\text { Air curing and } \\
\text { heat curing }\end{array}$ & Flow and compressive strengths & $\begin{array}{l}212 \mathrm{MPa} \text { for mixtures with } 17 \% \text { RHA and } \\
20 \% \text { GGBS after } 360 \text { days of curing at both } \\
\text { air curing and heat curing at } 60{ }^{\circ} \mathrm{C}\end{array}$ \\
\hline [112] & - & 4, 10 and 15 & $\begin{array}{c}\text { WGP }(5 \%, 10 \% \text { and } \\
16 \%)\end{array}$ & Standard water curing & Compressive strengths & $\begin{array}{c}57 \mathrm{MPa} \text { for mixtures with } 4 \% \text { RHA and } 16 \% \\
\text { WGP after } 28 \text { days of curing }\end{array}$ \\
\hline [114] & 0,10 and 15 & $10,15,20$ and 25 & $\begin{array}{c}\text { GGBS }(0,10 \% \text { and } \\
15 \%)\end{array}$ & Standard water curing & $\begin{array}{l}\text { Water Permeability, elasticity } \\
\text { modulus, the strengths of (bond, } \\
\text { flexural, splitting tensile and } \\
\text { compressive), air content and Slump }\end{array}$ & $\begin{array}{l}\text { 202.3 MPa for mixtures with 20\% RHA after } \\
\text { 91 days of curing. }\end{array}$ \\
\hline [115] & $\begin{array}{l}12,14.4,16.8,19.2 \\
\text { and } 21.6\end{array}$ & $\begin{array}{l}2.4,4.8,7.2,9.2 \\
\quad \text { and } 12\end{array}$ & - & $\begin{array}{l}\text { Standard water and } \\
\text { steam curing }\end{array}$ & $\begin{array}{c}\text { Compressive strengths, flexure } \\
\text { strengths, splitting tensile strengths, } \\
\text { porosity, rapid chloride penetration } \\
\text { and XRD }\end{array}$ & $\begin{array}{l}230 \mathrm{MPa} \text { for mixtures with } 7.2 \% \text { RHA and } \\
16.8 \% \text { SF after } 28 \text { days of steam curing. }\end{array}$ \\
\hline [116] & $0,9,10$ and 17 & 9,10 and 17 & - & Air curing & $\begin{array}{l}\text { Compressive strengths, TGA, XRD, } \\
\text { SEM and MIP. }\end{array}$ & $\begin{array}{l}190 \mathrm{MPa} \text { for mixture with } 17 \% \text { RHA and } \\
17 \% \text { SF after } 91 \text { days of curing }\end{array}$ \\
\hline
\end{tabular}


Moreover, it is clear that the UHPC made from RHA had less autogenous shrinkage than SF. This behavior can be attributed to RHA acting as an internal curing agent [117-119], thus reducing the self-desiccation of UHPC and consequently, causing the autogenous shrinkage to decline.

Furthermore, the combination of RHA and SF might impart better performance in UHPC than that of RHA or SF alone. The best combination ratio provided by the previous works (Table 4 ) was $1 / 1$ (10\% for each material) $[2,110]$ or $2 / 3$ [113] (SF/RHA).

Additionally, it is observed that there is an absence of investigates addressed the long-term performance (more than one year) of RHA-based UHPC. Additionally, limited research discussed the production cost of UHPC-incorporated RHA and compared it with that produced with SF.

\subsection{Carbon Footprint and Energy Consumption of Mineral Admixtures-Based Concrete}

As mentioned earlier, the cement industry produces high amounts of carbon dioxide. Among the effective technologies to reduce these emissions are the reduction of the content of high-energy clinker in Portland cement through the use of waste from other industries, the development of production technology, the use of alternative fuels and increasing the content of alternative cementitious materials [120]. Among these technologies, the use of cement mixed with SCMs (such as SF, GGBS, FA and RHA) is the most practical and economical method, and it can be directly applied in the field of ready-mix concrete [121]. In general, the $\mathrm{CO}_{2}$ emissions associated with cement production is about 0.930 (ton $/ \mathrm{CO}_{2}$ eq./ton) [122], while the emissions of GGBS, FA, SF, and MK related to their replacement levels from cement are (0.052-0.143), (0.004-0.027), (0.028) and (0.330-0.423) at typical replacement levels of $(40 \%),(20 \%),(5-10 \%)$ and $(8-20 \%)$, respectively [123].

From the above table, it is noted that the carbon emissions of metakaolin are significantly higher than the rest of SCMs, which are about half of those coming from the cement industry. The reason for this is due to the high temperature used in calcination, which is estimated at $750{ }^{\circ} \mathrm{C}[124]$.

On the other hand, the environmental impact of these materials in concrete was addressed by several investigations. For instance, Wu et al. [122] studied the energy intensity and $\mathrm{CO}_{2}$ emission of high-performance green cement containing high volumes of GGBS and FA (ranged from 0 to $90 \%$ ) and superfine cement. Results indicated that the green cement that contained $70 \%$ mineral admixtures showed energy consumption and $\mathrm{CO}_{2}$ emission of $47.3 \%$ and $40.9 \%$, respectively, of that of the Portland cement.

Shi et al. [125] investigated the preparation of UHPC with a low environmental impact. SF, FA, GGBS and nano silica (NS) were used as cement replacement materials. Results indicated that it is possible to produce UHPC with less than $200 \mathrm{~kg} / \mathrm{m}^{3}$ cement by optimizing the binder content and curing systems. The embodied $\mathrm{CO}_{2}$ of this concrete was $3 \mathrm{~kg} / \mathrm{MPa} . \mathrm{m}^{3}$, compared to $5.5-7 \mathrm{~kg} / \mathrm{MPa} \cdot \mathrm{m}^{3}$ for conventional UHPC. Moreover, the environmental impact of low-cement-UHPC was significantly improved when GGBS was added compared with FA. Furthermore, the ternary blend of GGBS, FA and SF led to another reduction in the carbon dioxide index.

Yang et al. [121] studied the reduction of carbon dioxide emission of SCMs (such as GGBS, SF and FA) from ordinary Portland cement (OPC) in concrete based on a Korean lifecycle inventory. Results showed that the OPC-based concrete had the highest $\mathrm{CO}_{2}$ intensity. Contrarily, concrete comprised of OPC+ GGBS+ FA had the lowest $\mathrm{CO}_{2}$ intensity compared to all other types of concrete. Additionally, it was recorded that the higher the SCMs, the lower is the $\mathrm{CO}_{2}$ intensity up to $15-20 \%$ of SCMs. After that, the reduction rate was gradually slow.

Henry and Lynam [126] studied the embodied energy of RHA for the manufacturing of sustainable cement. They found that using RHA as a partial substitution of cement could reduce the carbon footprint which was emitted during cement manufacturing. Moreover, using RHA as cement replacement material minimized the embodied energy and led to a more sustainably built environment. 


\section{Discussion}

Regarding the four SCMs (FA, MK, GGBS and RHA) considered in this study and their impact on different characteristics of UHPC relating to SF, it can be noted from the literature that $\mathrm{SF}$ had better strengths (especially compressive strengths property) than FA, MK and GGBS. Therefore, they are often blended with SF in the production of UHPC. The application of accelerated curing or combining them with SF may enhance the strength's performance. On the other hand, RHA had comparable or even superior strengths relative to SF. Nevertheless, strength should not be the sole criterion for comparison, as the main aims of using such materials are manufacturing UHPC with less cost and environmental impact. Therefore, all benefits should be considered together with other characteristics of UHPC throughout the comparison process. Moreover, using SCMs other than SF, it is possible to increase the cement replacement percentages up to $40 \%$ or $60 \%$ (especially for FA and GGBS), which means less $\mathrm{CO}_{2}$ emissions into the atmosphere and energy consumption. It is difficult to reach such substitution ratios with SF due to the restriction imposed by international standards. Furthermore, FA and GGBS enhanced the fluidity of UHPC (as compared to SF), which reduces the superplasticizer demand and enhances the compactness. On the other hand, regardless of the type of SCM, previous research has agreed that the microstructure of these materials, as well as SF, was dense, and the porosity had decreased significantly after they were utilized as alternatives to cement.

Otherwise, different replacement ratios for each of FA, MK, GGBS and RHA were recommended in the previous works. These differences could be explained by knowing that the impact of SCMs in UHPC is affected by their composition and fineness, as well as pozzolanic activity. Thus, the best replacement ratio for each material may differ accordingly.

Considering the reviewed investigations, it is noted that for experimental investigations that have utilized RHA as a replacement for SF, there is a lack of information available about the use of high levels of this substance in UHPC, especially since most of the previous investigates have proven that it is a successful alternative to SF. Furthermore, in most of the research that utilized high levels of SCMs, the resulting UHPC alkalinity was not examined, which is affected by the depletion of calcium hydroxide (as a result of its reaction with SCMs), which may affect the protection of buried steel fibers within it from corrosion. Additionally, limited investigations addressed the long-term performance (more than 180 days) of SCMs in the production of UHPC.

As for the environmental impact, it was found that there are limited studies in the literature that discussed the comparison between alternative cementitious materials with silica fume in the production of reactive powder concrete, in terms of their carbon dioxide footprint.

In general, however, when comparing carbon emissions in concrete containing these materials, it is clear that FA and GGBS are less emitting compared to other cement materials, and that GGBS is less than FA. Nevertheless, the presence of SF with FA and GGBS may lead to an additional reduction in $\mathrm{CO}_{2}$ emissions.

It is also worth noting that the comparison of SCMs should include not only the production processes of the material itself, but also the amount of strength produced and its relationship to the environmental impact, and the type of curing used and the proportions of cement replacement play an important role in the comparison. Therefore, comparing the carbon emissions of the various materials used in the production of concrete powders requires comprehensive life cycle assessment studies, which take into account all the above-mentioned parameters.

\section{Conclusions}

This paper reviewed the investigates that utilized SCMs other than SF in the manufacturing of UHPC and comparing their performance in comparison to that of SF. The following conclusions are drawn:

1. There are few studies that have dealt with carbon dioxide emissions and the energy consumed for SCMs in the manufacture of UHPC, taking into account materials 
manufacturing processes, the resulted compressive strength, the curing used and other details of concrete.

2. Among the SCMs that have been studied, GGBS can be considered the lowest environmentally impactful in the manufacture of UHPC. The carbon dioxide emissions are significantly reduced with the combined use of GGBS, FA and SF.

3. The grain particle size and accelerating curing are important parameters in FAbased UHPC.

4. The FA is usually utilized together with SF or GGBS in the production of UHPC, in order to compensate for the slow strengths development of FA at early ages.

5. There is a scarcity of information about the comparison in the behavior between the two types of FA (Type $C$ and F) under the impact of different curing systems.

6. From an environmental point of view and to reduce the cost of concrete, UHPC with compressive strengths of not less than $150 \mathrm{MPa}$ can be produced by combination FA + SF (as cement replacement materials) in the percentages of $(40 \%+5.5 \%)$ under steam curing or $(20 \%+5 \%)$ or under standard curing, respectively.

7. The GGBS can be utilized together with SF in the production of UHPC with better performance and environmental characteristics than SF alone. The recommended combination dosage ranged from 1.2 to 2 (by weight of cement for both materials).

8. There is an optimum fineness of GGBS when utilized with SF in UHPC, beyond and before it, the strengths are reduced from its maximum value.

9. The accelerated curing can increase the replacement level of cement with GGBS in UHPC. Nevertheless, if an appropriate mix proportion is utilized, utilizing normal curing for cost-end energy reduction purposes is considered satisfactory.

10. The SF has better performance than MK in the production of UHPC.

11. The compressive strengths/cost per $1 \mathrm{~m} 3$ and the material/cement packing density should be taken into account when making a comparison between SCMs in the production of UHPC.

12. The cement could be substituted with $M K$ in a proportion of $25 \%$ (by weight) to produce UHPC with an equivalent or a slight reduction in the mechanical performance compared to SF.

13. RHA can replace SF partially or completely in UHPC, as a result of its promising performance in hardened and fresh characteristics and its similar chemical composition.

14. The internal curing characteristic of RHA has made it superior to the performance of $\mathrm{SF}$ in later ages in terms of strengths development and shrinkage reduction.

15. The combination of RHA and SF ( $10 \%$ for each material) can give a better performance than if each substance was utilized separately.

16. In comparison to all SCMs investigated in this review, SF had the highest strength among these materials (at the same replacement level) except for RHA. Their combinations with SF or applying accelerated curing may limit strength reduction, or even recover it. Nevertheless, the other benefits such as the possibility of using high substitution ratios of these materials with cement, cost reduction and improving the environment should be taken into account during the comparison.

\section{Recommendations for Future Works}

Based on reviewing and analysis of the previous research, the following recommendations are suggested for future works:

- $\quad$ Studying the long-term performance of UHPC made from SCMs other than SF.

- Investigation of the impact of using a high volume fraction of RHA on different characteristics of UHPC.

- Examining the alkalinity of the produced UHPC made with high content of SCMs, which is affected by calcium hydroxide depletion.

- $\quad$ Performing comprehensive life cycle assessment for UHPC regarding the different types of SCMs. 
Author Contributions: Conceptualization, A.S.; methodology, A.S., M.N., Z.A.-K. and Z.A.M.; validation, A.S. and M.N.; formal analysis, A.S., M.N., P.K. and K.H.; investigation, A.S.; resources, A.S.; data curation, A.S., M.N., P.K., O.A.-H. and K.H.; writing-original draft preparation, A.S., M.N., M.A.H., Z.A.-K. and Z.A.M.; writing-review and editing, A.S., M.N., M.A.H., Z.A.-K. and Z.A.M.; visualization, A.S. and M.N.; supervision, A.S., M.N., O.A.-H., P.K. and R.A.; and project administration, A.S., M.N., P.K. and R.A. All authors have read and agreed to the published version of the manuscript.

Funding: This research received no external funding.

Acknowledgments: The authors would like to thank Al-Furat Al-Awsat Technical University and Liverpool John Moores University for providing technical support for this research.

Conflicts of Interest: The authors declare no conflict of interest.

\section{References}

1. Wang, X.; Yu, R.; Shui, Z.; Zhao, Z.; Song, Q.; Yang, B.; Fan, D. Development of a novel cleaner construction product: Ultra-high performance concrete incorporating lead-zinc tailings. J. Clean. Prod. 2018, 196, 172-182. [CrossRef]

2. Van Tuan, N.; Ye, G.; Van Breugel, K.; Fraaij, A.L.A.; Dai Bui, D. The study of using rice husk ash to produce ultra high performance concrete. Constr. Build. Mater. 2011, 25, 2030-2035. [CrossRef]

3. Shi, C.; Wu, Z.; Xiao, J.; Wang, D.; Huang, Z.; Fang, Z. A review on ultra high performance concrete: Part I. Raw materials and mixture design. Constr. Build. Mater. 2015, 101, 741-751. [CrossRef]

4. Shafieifar, M.; Farzad, M.; Azizinamini, A. Experimental and numerical study on mechanical properties of Ultra High Performance Concrete (UHPC). Constr. Build. Mater. 2017, 156, 402-411. [CrossRef]

5. Tayeh, B.A.; Bakar, B.H.A.; Johari, M.A.M. Characterization of the interfacial bond between old concrete substrate and ultra high performance fiber concrete repair composite. Mater. Struct. 2013, 46, 743-753. [CrossRef]

6. Yu, K.-Q.; Yu, J.-T.; Dai, J.-G.; Lu, Z.-D.; Shah, S.P. Development of ultra-high performance engineered cementitious composites using polyethylene (PE) fibers. Constr. Build. Mater. 2018, 158, 217-227. [CrossRef]

7. Richard, P.; Cheyrezy, M. Composition of reactive powder concretes. Cem. Concr. Res. 1995, 25, 1501-1511. [CrossRef]

8. Cheyrezy, M.; Maret, V.; Frouin, L. Microstructural analysis of RPC (reactive powder concrete). Cem. Concr. Res. 1995, 25, 1491-1500. [CrossRef]

9. Yunsheng, Z.; Wei, S.; Sifeng, L.; Chujie, J.; Jianzhong, L. Preparation of C200 green reactive powder concrete and its staticdynamic behaviors. Cem. Concr. Compos. 2008, 30, 831-838. [CrossRef]

10. Yiğiter, H.; Aydın, S.; Yazıcı, H.; Yardımcı, M.Y. Mechanical performance of low cement reactive powder concrete (LCRPC). Compos. Part B Eng. 2012, 43, 2907-2914. [CrossRef]

11. Zheng, W.; Luo, B.; Wang, Y. Compressive and tensile properties of reactive powder concrete with steel fibres at elevated temperatures. Constr. Build. Mater. 2013, 41, 844-851. [CrossRef]

12. Liu, K.; Yu, R.; Shui, Z.; Li, X.; Ling, X.; He, W.; Yi, S.; Wu, S. Effects of pumice-based porous material on hydration characteristics and persistent shrinkage of ultra-high performance concrete (UHPC). Materials 2019, 12, 11. [CrossRef]

13. Habel, K.; Viviani, M.; Denarié, E.; Brühwiler, E. Development of the mechanical properties of an ultra-high performance fiber reinforced concrete (UHPFRC). Cem. Concr. Res. 2006, 36, 1362-1370. [CrossRef]

14. Alsalman, A.; Dang, C.N.; Hale, W.M. Development of ultra-high performance concrete with locally available materials. Constr. Build. Mater. 2017, 133, 135-145. [CrossRef]

15. Graybeal, B. UHPC making strides. Public Roads 2009, 72, 17-21.

16. Schmidt, M.; Fehling, E. Ultra-high-performance concrete: Research, development and application in Europe. ACI Spec. Publ. 2005, 228, 51-78.

17. Graybeal, B.A. Compressive behavior of ultra-high-performance fiber-reinforced concrete. ACI Mater. J. 2007, $104,146$.

18. $\mathrm{Li}, \mathrm{J} . ; \mathrm{Wu}, \mathrm{C} . ; \mathrm{Liu}, \mathrm{Z} .-\mathrm{X}$. Comparative evaluation of steel wire mesh, steel fibre and high performance polyethylene fibre reinforced concrete slabs in blast tests. Thin-Walled Struct. 2018, 126, 117-126. [CrossRef]

19. Li, P.P.; Yu, Q.L.; Brouwers, H.J.H. Effect of PCE-type superplasticizer on early-age behaviour of ultra-high performance concrete (UHPC). Constr. Build. Mater. 2017, 153, 740-750. [CrossRef]

20. Sujatha, T.; Basanthi, D. Modified Reactive Powder Concrete. Int. J. Educ. Appl. Res. 2014, 4, 85-87.

21. Li, P.P.; Yu, Q.L.; Brouwers, H.J.H. Effect of coarse basalt aggregates on the properties of Ultra-high Performance Concrete (UHPC). Constr. Build. Mater. 2018, 170, 649-659. [CrossRef]

22. Yoo, D.-Y.; Banthia, N. Mechanical properties of ultra-high-performance fiber-reinforced concrete: A review. Cem. Concr. Compos. 2016, 73, 267-280. [CrossRef]

23. Yu, R.; Van Beers, L.; Spiesz, P.; Brouwers, H.J.H. Impact resistance of a sustainable Ultra-High Performance Fibre Reinforced Concrete (UHPFRC) under pendulum impact loadings. Constr. Build. Mater. 2016, 107, 203-215. [CrossRef]

24. Chen, T.; Gao, X.; Ren, M. Effects of autoclave curing and fly ash on mechanical properties of ultra-high performance concrete. Constr. Build. Mater. 2018, 158, 864-872. [CrossRef] 
25. Yazıc1, H.; Deniz, E.; Baradan, B. The effect of autoclave pressure, temperature and duration time on mechanical properties of reactive powder concrete. Constr. Build. Mater. 2013, 42, 53-63. [CrossRef]

26. Alkaysi, M.; El-Tawil, S.; Liu, Z.; Hansen, W. Effects of silica powder and cement type on durability of ultra high performance concrete (UHPC). Cem. Concr. Compos. 2016, 66, 47-56. [CrossRef]

27. Garas, V.Y.; Kurtis, K.E.; Kahn, L.F. Creep of UHPC in tension and compression: Effect of thermal treatment. Cem. Concr. Compos. 2012, 34, 493-502. [CrossRef]

28. Tai, Y.-S.; El-Tawil, S. Effect of component materials and mixing protocol on the short-term performance of generic ultra-highperformance concrete. Constr. Build. Mater. 2020, 238, 117703. [CrossRef]

29. Wille, K.; Naaman, A.E.; El-Tawil, S.; Parra-Montesinos, G.J. Ultra-high performance concrete and fiber reinforced concrete: Achieving strength and ductility without heat curing. Mater. Struct. 2012, 45, 309-324. [CrossRef]

30. Wille, K.; Naaman, A.E.; Parra-Montesinos, G.J. Ultra-High Performance Concrete with Compressive Strength Exceeding 150 MPa (22 ksi): A Simpler Way. ACI Mater. J. 2011, 108, 46-54.

31. Azmee, N.M.; Shafiq, N. Ultra-high performance concrete: From fundamental to applications. Case Stud. Constr. Mater. 2018, 9, e00197. [CrossRef]

32. Voo, Y.L. Ultra High Performance Concrete"-Technology for Present and Future ACI Singapore. In Proceedings of the Building Construction Authority Joint Seminar on Concrete for Sustainability, Productivity and the Future, Singapore, 30 March 2017.

33. Pyo, S.; Tafesse, M.; Kim, B.-J.; Kim, H.-K. Effects of quartz-based mine tailings on characteristics and leaching behavior of ultra-high performance concrete. Constr. Build. Mater. 2018, 166, 110-117. [CrossRef]

34. Racky, P. Cost-effectiveness and sustainability of UHPC. In Proceedings of the International Symposium on Ultra High Performance Concrete, Kassel, Germany, 13-15 September 2004; pp. 797-805.

35. Graybeal, B. Ultra-High Performance Concrete; US Department of Transportation: Washington, DC, USA, 2011.

36. Allena, S.; Newtson, C.M. Ultra-high strength concrete mixtures using local materials. J. Civ. Eng. Archit. 2011, 5, 322-330.

37. Tam, C.M.; Tam, V.W.Y.; Ng, K.M. Assessing drying shrinkage and water permeability of reactive powder concrete produced in Hong Kong. Constr. Build. Mater. 2012, 26, 79-89. [CrossRef]

38. Shubbar, A.A.; Jafer, H.; Abdulredha, M.; Al-Khafaji, Z.S.; Nasr, M.S.; Al Masoodi, Z.; Sadique, M. Properties of cement mortar incorporated high volume fraction of GGBFS and CKD from 1 day to 550 days. J. Build. Eng. 2020, 30, 101327. [CrossRef]

39. Reddy, V.S.G.; Rao, V.R. Eco-friendly blocks by blended materials. Int. J. Eng. 2017, 30, 636-642.

40. Kanthe, V.; Deo, S.; Murmu, M. Combine use of fly ash and rice husk ash in concrete to improve its properties. Int. J. Eng. 2018, 31, 1012-1019.

41. Nasr, M.S.; Shubbar, A.A.; Abed, Z.-A.R.; Ibrahim, M.S. Properties of eco-friendly cement mortar contained recycled materials from different sources. J. Build. Eng. 2020, 31, 101444. [CrossRef]

42. Hawileh, R.A.; Abdalla, J.A.; Fardmanesh, F.; Shahsana, P.; Khalili, A. Performance of reinforced concrete beams cast with different percentages of GGBS replacement to cement. Arch. Civ. Mech. Eng. 2017, 17, 511-519. [CrossRef]

43. Nasr, M.S.; Hasan, Z.A.; Abed, M.K.; Dhahir, M.K.; Najim, W.N.; Shubbar, A.A.; Dhahir, H.Z. Utilization of High Volume Fraction of Binary Combinations of Supplementary Cementitious Materials in the Production of Reactive Powder Concrete. Period. Polytech. Civ. Eng. 2021, 65, 335-343. [CrossRef]

44. Ahmad, S.; Hakeem, I.; Maslehuddin, M. Development of UHPC mixtures utilizing natural and industrial waste materials as partial replacements of silica fume and sand. Sci. World J. 2014, 2014, 713531. [CrossRef]

45. Soliman, N.A.; Tagnit-Hamou, A. Partial substitution of silica fume with fine glass powder in UHPC: Filling the micro gap. Constr. Build. Mater. 2017, 139, 374-383. [CrossRef]

46. Matte, V.; Moranville, M. Durability of reactive powder composites: Influence of silica fume on the leaching properties of very low water/binder pastes. Cem. Concr. Compos. 1999, 21, 1-9. [CrossRef]

47. Gursel, A.P.; Maryman, H.; Ostertag, C. A life-cycle approach to environmental, mechanical, and durability properties of "green" concrete mixes with rice husk ash. J. Clean. Prod. 2016, 112, 823-836. [CrossRef]

48. Rabehi, B.; Ghernouti, Y.; Boumchedda, K. Strength and compressive behaviour of ultra high-performance fibre-reinforced concrete (UHPFRC) incorporating Algerian calcined clays as pozzolanic materials and silica fume. Eur. J. Environ. Civ. Eng. 2013, 17, 599-615. [CrossRef]

49. Peng, Y.; Zhang, J.; Liu, J.; Ke, J.; Wang, F. Properties and microstructure of reactive powder concrete having a high content of phosphorous slag powder and silica fume. Constr. Build. Mater. 2015, 101, 482-487. [CrossRef]

50. Yazıcı, H.; Yiğiter, H.; Karabulut, A.Ş.; Baradan, B. Utilization of fly ash and ground granulated blast furnace slag as an alternative silica source in reactive powder concrete. Fuel 2008, 87, 2401-2407. [CrossRef]

51. Peng, Y.; Hu, S.; Ding, Q. Preparation of reactive powder concrete using fly ash and steel slag powder. J. Wuhan Univ. Technol. Sci. Ed. 2010, 25, 349-354. [CrossRef]

52. Shi, T.; Chen, B.; Shi, H. Research on the proportion of reactive powder concrete with blast-furnace slag. Mater. Sci. Eng. 2005, 23, 867.

53. Yan, G.A.O.; Shuzhen, L.V.; Zhongyuan, L.U.; Jun, L.I.; Dan, Z. Preparation and properties of reactive powder concrete with circulating fluidized bed combustion fly ash. Chin. J. Mater. Res. 2014, 28, 59-66.

54. Xiao, R.; Deng, Z.; Lan, M.; Shen, C. Experiment research on proportions of reactive powder concrete without silica fume. J. Jilin Univ. Eng. Technol. Ed. 2013, 3, 671-676. 
55. Zhang, H.; Ji, T.; He, B.; He, L. Performance of ultra-high performance concrete (UHPC) with cement partially replaced by ground granite powder (GGP) under different curing conditions. Constr. Build. Mater. 2019, 213, 469-482. [CrossRef]

56. Ma, J.; Schneider, H. Properties of ultra-high-performance concrete. Leipzig Annu. Civ. Eng. Rep. 2002, 7, 25-32.

57. Soutsos, M.N.; Millard, S.G.; Karaiskos, K. Mix design, mechanical properties, and impact resistance of reactive powder concrete (RPC). In Proceedings of the International Workshop on High Performance Fibre-Reinforced Cementitious Composites in Structural Applications, London, UK, 23 May 2005; pp. 549-560.

58. Yazıc1, H. The effect of curing conditions on compressive strength of ultra high strength concrete with high volume mineral admixtures. Build. Environ. 2007, 42, 2083-2089. [CrossRef]

59. Li, Z.; Rangaraju, P.R. Development of UHPC Using Ternary Blends of Ultra-Fine Class F Fly Ash, Meta-kaolin and Portland Cement. In Proceedings of the First International Interactive Symposium on Ultra-High Performance Concrete, Des Moines, IO, USA, 18-20 July 2016.

60. Mosaberpanah, M.A. Utilizing Rice Husk Ash as Supplement to Cementitious Materials on Performance of Ultra High Performance Concrete-A review. Mater. Today Sustain. 2020, 7, 100030. [CrossRef]

61. Wang, D.; Shi, C.; Wu, Z.; Xiao, J.; Huang, Z.; Fang, Z. A review on ultra high performance concrete: Part II. Hydration, microstructure and properties. Constr. Build. Mater. 2015, 96, 368-377. [CrossRef]

62. Tayeh, B.A.; Aadi, A.S.; Hilal, N.N.; Bakar, B.H.A.; Al-Tayeb, M.M.; Mansour, W.N. Properties of ultra-high-performance fiber-reinforced concrete (UHPFRC)—A review paper. In AIP Conference Proceedings; AIP Publishing LLC: Melville, NY, USA, 2019; Volume 2157, p. 20040.

63. Mishra, O.; Singh, S.P. An overview of microstructural and material properties of ultra-high-performance concrete. J. Sustain. Cem. Mater. 2019, 8, 97-143. [CrossRef]

64. Khayat, K.H.; Meng, W.; Vallurupalli, K.; Teng, L. Rheological properties of ultra-high-performance concrete-An overview. Cem. Concr. Res. 2019, 124, 105828. [CrossRef]

65. Shaikh, F.U.A.; Luhar, S.; Arel, H.Ş.; Luhar, I. Performance evaluation of Ultrahigh performance fibre reinforced concrete-A review. Constr. Build. Mater. 2020, 232, 117152. [CrossRef]

66. Cao, S.; Hou, X.; Rong, Q. Dynamic compressive properties of reactive powder concrete at high temperature: A review. Cem. Concr. Compos. 2020, 110, 103568. [CrossRef]

67. Aitcin, P.-C. Supplementary cementitious materials and blended cements. In Science and Technology of Concrete Admixtures; Elsevier: Amsterdam, The Netherlands, 2016; pp. 53-73.

68. Benson, C.H.; Bradshaw, S. User Guideline for Coal Fly Ash in Green Infrastructure Construction; University of Wisconsin-Madison: Madison, WI, USA, 2011.

69. Das, S.K. Yudhbir Geotechnical characterization of some Indian fly ashes. J. Mater. Civ. Eng. 2005, 17, 544-552. [CrossRef]

70. Yardımcı, M.Y.; Aydın, S.; Karabulut, A.Ş. Mechanical properties of reactive powder concrete containing mineral admixtures under different curing regimes. Constr. Build. Mater. 2009, 23, 1223-1231. [CrossRef]

71. Ferdosian, I.; Camões, A.; Ribeiro, M. High-volume fly ash paste for developing ultra-high performance concrete (UHPC). Ciência Tecnol. Dos Mater. 2017, 29, e157-e161. [CrossRef]

72. Zhang, J.; Zhao, Y.; Li, H. Experimental investigation and prediction of compressive strength of ultra-high performance concrete containing supplementary cementitious materials. Adv. Mater. Sci. Eng. 2017, 2017, 4563164. [CrossRef]

73. Bahedh, M.A.; Jaafar, M.S. Ultra high-performance concrete utilizing fly ash as cement replacement under autoclaving technique. Case Stud. Constr. Mater. 2018, 9, e00202. [CrossRef]

74. Gamal, I.K.; Elsayed, K.M.; Makhlouf, M.H.; Alaa, M. Properties of reactive powder concrete using local materials and various curing conditions. Eur. J. Eng. Res. Sci. 2019, 4, 74-83.

75. Alsalman, A.; Dang, C.N.; Martí-Vargas, J.R.; Hale, W.M. Mixture-proportioning of economical UHPC mixtures. J. Build. Eng. 2020, 27, 100970. [CrossRef]

76. Velázquez, S.; Monzó, J.; Borrachero, M.V.; Soriano, L.; Payá, J. Evaluation of the pozzolanic activity of spent FCC catalyst/fly ash mixtures in Portland cement pastes. Thermochim. Acta 2016, 632, 29-36. [CrossRef]

77. Radlinski, M.; Olek, J. Investigation into the synergistic effects in ternary cementitious systems containing portland cement, fly ash and silica fume. Cem. Concr. Compos. 2012, 34, 451-459. [CrossRef]

78. Sumer, M. Compressive strength and sulfate resistance properties of concretes containing Class F and Class $\mathrm{C}$ fly ashes. Constr. Build. Mater. 2012, 34, 531-536. [CrossRef]

79. Yildirim, H.; Sümer, M.; Akyüncü, V.; Gürbüz, E. Comparison on efficiency factors of F and C types of fly ashes. Constr. Build. Mater. 2011, 25, 2939-2947. [CrossRef]

80. Oner, A.; Akyuz, S. An experimental study on optimum usage of GGBS for the compressive strength of concrete. Cem. Concr. Compos. 2007, 29, 505-514. [CrossRef]

81. Islam, A.; Alengaram, U.J.; Jumaat, M.Z.; Bashar, I.I. The development of compressive strength of ground granulated blast furnace slag-palm oil fuel ash-fly ash based geopolymer mortar. Mater. Des. 2014, 56, 833-841. [CrossRef]

82. Yazıcı, H.; Yardımcı, M.Y.; Yiğiter, H.; Aydın, S.; Türkel, S. Mechanical properties of reactive powder concrete containing high volumes of ground granulated blast furnace slag. Cem. Concr. Compos. 2010, 32, 639-648. [CrossRef] 
83. Ghafari, E.; Costa, H.; Júlio, E.; Portugal, A.; Durães, L. Enhanced durability of ultra high performance concrete by incorporating supplementary cementitious materials. In Proceedings of the 2nd International Conference Microdurability, Delft, The Netherland, 11-13 April 2012; pp. 86-94.

84. Wang, C.; Yang, C.; Liu, F.; Wan, C.; Pu, X. Preparation of ultra-high performance concrete with common technology and materials. Cem. Concr. Compos. 2012, 34, 538-544. [CrossRef]

85. Gupta, S. Development of ultra-high performance concrete incorporating blend of slag and silica fume as cement replacement'. Int. J. Civ. Struct. Eng. Res 2014, 2, 35-51.

86. Randl, N.; Steiner, T.; Ofner, S.; Baumgartner, E.; Mészöly, T. Development of UHPC mixtures from an ecological point of view. Constr. Build. Mater. 2014, 67,373-378. [CrossRef]

87. Kim, H.; Koh, T.; Pyo, S. Enhancing flowability and sustainability of ultra high performance concrete incorporating high replacement levels of industrial slags. Constr. Build. Mater. 2016, 123, 153-160. [CrossRef]

88. Gupta, S. Effect of content and fineness of slag as high volume cement replacement on strength and durability of ultra-high performance mortar. J. Build. Mater. Struct. 2016, 3, 43-54.

89. Wu, Z.; Shi, C.; He, W. Comparative study on flexural properties of ultra-high performance concrete with supplementary cementitious materials under different curing regimes. Constr. Build. Mater. 2017, 136, 307-313. [CrossRef]

90. Ganesh, P.; Murthy, A.R. Tensile behaviour and durability aspects of sustainable ultra-high performance concrete incorporated with GGBS as cementitious material. Constr. Build. Mater. 2019, 197, 667-680. [CrossRef]

91. Nadiger, A.; Madhavan, M.K. Influence of Mineral Admixtures and Fibers on Workability and Mechanical Properties of Reactive Powder Concrete. J. Mater. Civ. Eng. 2019, 31, 4018394. [CrossRef]

92. Chidiac, S.E.; Panesar, D.K. Evolution of mechanical properties of concrete containing ground granulated blast furnace slag and effects on the scaling resistance test at 28 days. Cem. Concr. Compos. 2008, 30, 63-71. [CrossRef]

93. Song, S.; Sohn, D.; Jennings, H.M.; Mason, T.O. Hydration of alkali-activated ground granulated blast furnace slag. J. Mater. Sci. 2000, 35, 249-257. [CrossRef]

94. Beushausen, H.; Alexander, M.; Ballim, Y. Early-age properties, strength development and heat of hydration of concrete containing various South African slags at different replacement ratios. Constr. Build. Mater. 2012, 29, 533-540. [CrossRef]

95. Narmatha, M.; Felixkala, T. Experimental investigation of hpc using metakaolin and flyash with partial replacement of cement. In Proceedings of the INfrastructure Development for Environmental Conservation and Sustenance (INDECS-15), Hosur, India, 28-30 October 2015; p. 105.

96. Justice, J.M. Evaluation of Metakaolins for Use as Supplementary Cementitious Materials. Ph.D. Thesis, Georgia Institute of Technology, Atlanta, GA, USA, 2005.

97. Rougeau, P.; Borys, B. Ultra high performance concrete with ultrafine particles other than silica fume. In Proceedings of the International Symposium on Ultra High Performance Concrete, Kassel, Germany, 13-15 September 2004; Volume 32, pp. 213-225.

98. Staquet, S.; Espion, B. Early age autogenous shrinkage of UHPC incorporating very fine fly ash or metakaolin in replacement of silica fume. In Proceedings of the International Symposium on Ultra High Performance Concrete, Kessel, Germany, 13-15 September 2004; pp. 587-599.

99. Tafraoui, A.; Escadeillas, G.; Lebaili, S.; Vidal, T. Metakaolin in the formulation of UHPC. Constr. Build. Mater. 2009, 23, 669-674. [CrossRef]

100. Al-Azzawi, A.A.; Ali, A.S.; Risan, H.K. Behavior of ultra high performance concrete structures. ARPN J. Eng. Appl. Sci. 2011, 6, 95-109.

101. Nguyen Amanjean, E.; Vidal, T. Low Cost Ultra-High Performance Fiber Reinforced Concrete (UHPFRC) with Flash Metakaolin. In Proceedings of the Key Engineering Materials; Trans Tech Publishing: Bäch, Switzerland, 2015; Volume 629, pp. 55-63.

102. Li, Z. Drying shrinkage prediction of paste containing meta-kaolin and ultrafine fly ash for developing ultra-high performance concrete. Mater. Today Commun. 2016, 6, 74-80. [CrossRef]

103. Tafraoui, A.; Escadeillas, G.; Vidal, T. Durability of the ultra high performances concrete containing metakaolin. Constr. Build. Mater. 2016, 112, 980-987. [CrossRef]

104. Huang, W.; Kazemi-Kamyab, H.; Sun, W.; Scrivener, K. Effect of replacement of silica fume with calcined clay on the hydration and microstructural development of eco-UHPFRC. Mater. Des. 2017, 121, 36-46. [CrossRef]

105. Šeps, K.; Broukalová, I.; Chylík, R. Cement Substitutions in UHPC and their Influence on Principal Mechanical-Physical Properties. In IOP Conference Series: Materials Science and Engineering; IOP Publishing: Bristol, UK, 2019; Volume 522, p. 12009.

106. Wille, K.; Boisvert-Cotulio, C. Material efficiency in the design of ultra-high performance concrete. Constr. Build. Mater. 2015, 86, 33-43. [CrossRef]

107. Singhania, N.P.; Marg, M.; Rice Husk Ash. The Institute of Concrete Technology Newsletter, The Engineering Council (UK). 2004. Available online: https:/ / www.ricehuskash.com/publications / (accessed on 5 December 2021).

108. Van Tuan, N.; Ye, G.; van Breugel, K. Effect of rice husk ash on autogenous shrinkage of ultra high performance concrete. In Proceedings of the International RILEM Conference on Advances in Construction Materials through Science and Engineering, Hong Kong, China, 4-7 September 2010.

109. Van Tuan, N.; Ye, G.; Van Breugel, K.; Copuroglu, O. Hydration and microstructure of ultra high performance concrete incorporating rice husk ash. Cem. Concr. Res. 2011, 41, 1104-1111. [CrossRef] 
110. Tian, E.B.; Zhuang, Y.Z.; Wang, F.C. Research on Ultra-High Performance Concrete with Rice Husk Ash. In Proceedings of the Applied Mechanics and Materials; Trans Tech Publishing: Bäch, Switzerland, 2013; Volume 330, pp. 131-135.

111. Rößler, C.; Bui, D.-D.; Ludwig, H.-M. Rice husk ash as both pozzolanic admixture and internal curing agent in ultra-high performance concrete. Cem. Concr. Compos. 2014, 53, 270-278.

112. Asteray, B.; Oyawa, W.; Shitote, S. Experimental investigation on compressive strength of recycled reactive powder concrete containing glass powder and rice husk ash. J. Civ. Eng. Res. 2017, 7, 124-129.

113. Huang, H.; Gao, X.; Wang, H.; Ye, H. Influence of rice husk ash on strength and permeability of ultra-high performance concrete. Constr. Build. Mater. 2017, 149, 621-628. [CrossRef]

114. Amin, M. Properties of reactive powder concrete incorporating silica fume and rice husk ash. Chall. J. Concr. Res. Lett. 2018, 9, 114-127. [CrossRef]

115. Vigneshwari, M.; Arunachalam, K.; Angayarkanni, A. Replacement of silica fume with thermally treated rice husk ash in Reactive Powder Concrete. J. Clean. Prod. 2018, 188, 264-277. [CrossRef]

116. Kang, S.-H.; Hong, S.-G.; Moon, J. The use of rice husk ash as reactive filler in ultra-high performance concrete. Cem. Concr. Res. 2019, 115, 389-400. [CrossRef]

117. Rößler, C.; Bui, D.-D.; Ludwig, H.-M. Mesoporous structure and pozzolanic reactivity of rice husk ash in cementitious system. Constr. Build. Mater. 2013, 43, 208-216.

118. Sharifi, N.P.; Jafferji, H.; Reynolds, S.E.; Blanchard, M.G.; Sakulich, A.R. Application of lightweight aggregate and rice husk ash to incorporate phase change materials into cementitious materials. J. Sustain. Cem. Mater. 2016, 5, 349-369. [CrossRef]

119. Justs, J.; Wyrzykowski, M.; Bajare, D.; Lura, P. Internal curing by superabsorbent polymers in ultra-high performance concrete. Cem. Concr. Res. 2015, 76, 82-90. [CrossRef]

120. Sanytsky, M.; Kropyvnytska, T.; Fic, S.; Ivashchyshyn, H. Sustainable low-carbon binders and concretes. In E3S Web of Conferences; EDP Sciences: Les Ulis, France, 2020; Volume 166, p. 6007.

121. Yang, K.-H.; Jung, Y.-B.; Cho, M.-S.; Tae, S.-H. Effect of supplementary cementitious materials on reduction of $\mathrm{CO}_{2}$ emissions from concrete. J. Clean. Prod. 2015, 103, 774-783. [CrossRef]

122. Wu, M.; Zhang, Y.; Ji, Y.; Liu, G.; Liu, C.; She, W.; Sun, W. Reducing environmental impacts and carbon emissions: Study of effects of superfine cement particles on blended cement containing high volume mineral admixtures. J. Clean. Prod. 2018, 196, 358-369. [CrossRef]

123. Black, L. Low clinker cement as a sustainable construction material. In Sustainability of Construction Materials; Elsevier: Amsterdam, The Netherlands, 2016; pp. 415-457.

124. Heath, A.; Paine, K.; McManus, M. Minimising the global warming potential of clay based geopolymers. J. Clean. Prod. 2014, 78, 75-83. [CrossRef]

125. Shi, Y.; Long, G.; Ma, C.; Xie, Y.; He, J. Design and preparation of ultra-high performance concrete with low environmental impact. J. Clean. Prod. 2019, 214, 633-643. [CrossRef]

126. Henry, C.S.; Lynam, J.G. Embodied energy of rice husk ash for sustainable cement production. Case Stud. Chem. Environ. Eng. 2020, 2, 100004. [CrossRef] 